\title{
Kamulaştırmasız el atma ve hukuki el atma kavramlarının tüzel gelişiminin incelenmesi
}

\author{
Ahmet Yılmaz ${ }^{1 *}$ ii \\ ${ }^{1}$ Yıldız Teknik Üniversitesi, Davutpaşa Kampüsü, Inşaat Fakültesi, Harita Mühendisliği Bölümü, Esenler, İstanbul, Türkiye.
}

Öz: Ülkemizde, kamulaştırma tüzesi içerisinde hem idarelerin hem de taşınmaz sahiplerinin en büyük sorunlarından biri, kamulaştırmasız el atma kavramıdır. Bu kavram, 1950 'lerden günümüze kadar farklı kanun düzenlemeleri ve yargı kararları ile șekillenen ve gelișen bir tüzel süreç yaşamıştır. Sürecin başlangıcında yalnızca fiili el atmalar, kamulaştırmasız el atma olarak değerlendirilirken; 2010 yılından itibaren hukuki el atmalar da kamulaştırmasız el atma olarak kabul edilmiştir. Bu durum, kamulaştırmasız el atma kavramının kapsamının hukuki el atmalar ile genişlemesine ve sorunun daha da büyümesine sebep olmuştur. Kamulaştırmasız el atmaların ve özellikle de hukuki el atmaların temel sebebi, imar programlarının ve imar planlarının idarelerin planda yer alan hizmet alanlarının edinimini sağlayacak finansmana ve diğer kaynaklara sahip olmaması sebebiyle uzun yıllar gerçekleştirilememesidir. Sorunun çözümüne ilişkin birçok yasal düzenleme yapılmıştır. Bu çalışmada, kamulaştırmasız el atma kavramının tüzel gelişiminin 1956 ile 2020 yılları arasındaki kanun düzenlemeleri ve yargı kararları bakımından incelenmesi amaçlanmıștır. Bu amaca ulaşmak üzere kamulaștırmasız el atma ve hukuki el atma kavramlarına ilişkin kanun düzenlemelerinin ve mahkeme kararlarının değerlendirmeleri; etkileri, kapsamları, içerikleri ve sonuçlar bakımından bir süreç içerisinde irdelenmiştir. Bu süreçte yapılan düzenlemeler, genellikle mülkiyet hakkına müdahale eden istisnai hükümleri içermektedir. Bu hükümler, yargı kararları ile iptal edilmesine rağmen kanun koyucu, bu kararlara karşı benzer hükümleri içeren yeni kanunlarla direnmiştir. Bu sürecin çözümüne ilişkin son düzenleme ise kamu tarafindan edinimi sağlanamayan hizmet alanlarında, malikleri tarafindan plandaki fonksiyonuna uygun özel tesis yapılabilmesidir. Çalışmanın sonucu olarak kamulaştırmasız el atma kavramı içerisinde, fiili ve hukuki el atma kavramlarının tüzel gelişimi, son düzenlemenin değerlendirmesi ve bu kavramlara ilişkin güncel hükümler verilmiştir.

Anahtar Sözcükler: Kamulaştırmasız el atma, Fiili el atma, Hukuki el atma

\section{Investigating the legal progress of confiscation without expropriation and confiscation without expropriation by plans}

Abstract: In our country, one of the biggest problems of both administrations and landowners in the expropriation legislation is the concept of confiscation without expropriation. This concept has experienced a legal process that has been shaped and developed through different regulations and judicial decisions from the 1950s until today. At the beginning of the legal process, only de facto expropriations were accepted as confiscation without expropriation, however, since 2010, interventions on property rights caused by urban development plans are also considered as confiscating without expropriation. This situation caused the expansion of the scope of confiscation without expropriation via confiscation without expropriation by plans and also caused an increase in the problem. The main reason of confiscation without expropriation and confiscation without expropriation by plans is the failure of the administrations to realize development programs and urban development plans due to the lack of financing and other resources. Many legal arrangements have been made regarding the solution of the problem. The aim of the study is to examine the legal development of confiscation without expropriation in terms of legal arrangements and judicial decisions between 1956 and 2020. In order to achieve this goal, evaluations of the legal arrangements and judicial decisions regarding the concepts of confiscation without expropriation and confiscation without expropriation by plans are examined as a process, in terms of their impact, scope, content and results. The regulations made in this process often include exceptional provisions that interferes with property right. Although these provisions are annulled by the judicial decisions, the legislator resists against these decisions via making new laws containing similar provisions. The final regulation regarding the solution of this process is that the service areas, which cannot be acquired by the public, can be built by their owners in accordance with the function in the plan. As a result of the study, the legal development of the concepts de facto expropriation and confiscation without expropriation by plans in confiscation without expropriation, the evaluation of the last regulation and the current provisions regarding these concepts are given.

Keywords: Confiscation without expropriation, De facto expropriation, Confiscation without expropriation by plans 


\section{Giriş}

Anayasa'nın mülkiyet hakkını güvenceye alan 35'inci maddesine göre, herkes mülkiyet hakkına sahip olup bu hak yalnızca kamu yararı amacıyla kanunla sınırlandırılabilmekte ve kullanılması toplum yararına aykırı olamamaktadır. Mülkiyet hakk1, başkasına zarar vermemek ve kanunların koyduğu sınırlamalara uymak koşuluyla kişinin bir şey üzerinde dilediği biçimde yararlanma, tasarruf etme, başkasına devretme, kullanma, biçimini değiştirme, harcama ve tüketme yetkilerini kapsamaktadır.

Anayasa'nın 35'inci maddesi ile güvence altına alınmış olan mülkiyet hakkı ancak kamu yararının gerektirdiği durumlarda sınırlandırılabilmektedir. Mülkiyet hakkına getirilmiş anayasal sınırlamalardan bir tanesi de Anayasa'nın 46'ncı maddesinde öngörülen kamulaştırmadır (Çağdaş, 2001).

Kamulaştırma; kamu yararının zorunlu kıldığ 1 durumlarda, gerçek ya da özel hukuk tüzel kişilerinin mülkiyetinde bulunan taşınmazlara, devlet ve kamu tüzel kişilerince el konulması işlemidir. Anayasa'nın 46'ncı maddesi, kamulaştırmanın devlet ve kamu tüzel kişileri tarafından yapılabilmesi, kamu yararına dayanması, kanunlarda gösterilen esas ve usullere uygun olması, bedelinin peşin ve nakden gerçek karşılığa göre ödenmesi, istisnai durumlara ait esaslar gibi kamulaştırmaya ilişkin temel kuralları içermektedir. Bu kurallar, kamulaştırmanın anayasal unsurları olup bu unsurlardan birinin bulunmaması, kamulaştırma işlemini Anayasa'ya aykırı hâle getireceği gibi, Anayasa'nın 35'inci maddesi ile korunan mülkiyet hakkına da aykırılık oluşturacaktır.

Kamulaştırma işlemlerinde kamu, mülkiyet hakkına müdahalede bulunduğundan maliklerin temel hak ve özgürlüklerinin sınırlandırılmasına ilişkin genel ilkeleri düzenleyen Anayasa'nın 13'üncü maddesini de göz önünde bulundurmak zorundadır. $\mathrm{Bu}$ sebeple kamulaştırma ile mülkiyet hakkına yönelik yapılan müdahalelerin Anayasa’ya uygun olabilmesi için kamulaştırma ile yapılan müdahalenin kanuna dayanması, kamu yararı amacı taşıması ve ayrıca ölçülülük ilkesine göre yapılması gerekmektedir. Ancak idareler, ihtiyaç duyduğu taşınmazların mülkiyetini elde etmek için her zaman Anayasa'da ve ilgili kanunlarda belirtilen esaslara uygun olarak hareket etmemekte, bazı durumlarda bilerek ya da bilmeyerek, hiçbir yasa kuralına dayanmadan da kişilerin mülkiyet hakkına el atabilmektedir (Kaplan, 2012). İdarelerin sahip olduğu yetkiler ile kamulaştırmayı düzenleyen hükümler düşünüldüğünde idarelerin bu haklarla yetinmesi ve kamulaştırmasız el atma kavramının tüzemizde hiç oluşmaması gerekmektedir. Bu kapsamda kamulaştırmasız el atma kavramı, hukuk sistemimizde yer almamasına rağmen idarelerin hukuka aykırı eylemlerine karşı açılan davaların bir sonucu olarak ortaya çıkmıştır.

Kamulaştırmasız el atma, idarelerin kanun hükümlerine dayanan bir kamulaştırma kararı olmadan özel mülkiyette bulunan taşınmazlara el atmasıdır (Kaplan, 2012; Karaca, 2018; Yalçınduran, 2017). Kamulaştırmasız el atma kavramı, fiili ve hukuki olmak üzere ikiye ayrılmaktadır. Fiili el atmalar, idarelerin kamulaştırma yapmadan taşınmazlara fiilen müdahalesi ile ortaya çıkmakta; hukuki el atma ise fiili bir müdahale olmaksızın idarelerin eylemleri ya da eylemsizlikleri sonucunda uzun yıllar mülkiyet hakkının kısıtlanması ile ortaya çıkmaktadır. Kamu yararına dayanan sınırlandırmaların da en yaygın biçimi, imar planlarıdır. İdareler, imar planları ile kamunun gereksinim duyduğu hizmet alanları ve kamusal tesisler gibi alanlara ayrılan taşınmazların mülkiyet hakkını kısıtlamaktadır. Ancak bu durum, hukuki el atmanın oluşması için tek başına yeterli değildir çünkü mülkiyet hakkının kamu yararı olması durumunda sınırlandırılması mümkündür. Hukuki el atma, kamu tarafından yapılması gereken eylemlerin kanunlarda öngörülen süreler içinde gerçekleştirilememesinin bir sonucu olarak mülkiyet hakkındaki kısıtlılık durumunun uzun yıllar netleştirilememesi ile oluşmaktadır. Mülkiyet hakkından yoksun bırakma biçimindeki bu kısıtlamalar, hedeflenen kamu yararı ile malikin bireysel yararı arasında gözetilmesi gereken adil dengeyi bozmaktadır. Bu kapsamda, kamulaştırmasız el atmaların ve özellikle de hukuki el atmaların oluşmasının temel nedeni, imar planlarının uzun yıllar gerçekleştirilememesidir. 
Ülkemizde 1950 sonrası artan kentsel nüfus, arsa talebini arttırarak imar planlarının gerçekleştirilmesini gerektirse de bu gereksinim, finansal yetersizlikler sebebiyle sağlanamamıştır. 1950 yılında toplam nüfusun sadece $\% 25$ 'i kentsel alanlarda yaşarken bu oran, 1980 yılında \%44'e, 2010 yılında \% 76'ya (Demir \& Çabuk, 2010) ve son olarak adrese dayalı nüfus kayıt sisteminin 2019 yılı verilerine (URL-1) göre \%93'e yükselmişsir. Kentsel nüfusun hızla artması kentlerin genişlemesine sebep olmaktadır. Bu durum da altyapı, ulaşım, konut, sanayi alanı gibi donatı ve yerleşim alanlarına olan ihtiyacı arttırarak imar planlarının uygulanmasını gerektirmektedir. Ülkemizde, kentleşme ile imar planlarının gerçekleştirilmesi arasındaki ilişki, 3194 sayılı İmar Kanunu'nun 7'nci maddesinde, nüfusu 10 000'i aşan yerleşmelerde imar planlarının yapılması gerektiği şeklinde ifade edilmiştir. İmar planlarının yürürlüğe girmesiyle en geç üç ay içinde, uygulayıcı idareler tarafından bu planı tatbik etmek üzere beş yıllık imar programlarının hazırlanması gerekmektedir (3194/10). Planların gerçekleștirilmesini bütçe ve zaman açısından ortaya koyan imar programları, kentleşmenin zamanlamasını, düzenlemede kullanılacak yöntemi ve buna bağlı olarak da uygulama imar planlarında umumi hizmetlere ve resmî kurumlara ayrılan alanların kamu tarafından ne zaman ve nasıl edinileceğini belirtmesi bakımından önemlidir. Malikler, imar programında yer alan taşınmazlarının gelecekteki durumları (imar hakkı verilmesi, kamu tarafından edinimi) hakkında bilgi sahibi olacaktır. Böylelikle de katlanmaları gereken süre hakkında net bilgiye sahip olabileceklerdir. Ancak imar programlarının ve imar planlarının gerçekleştirilmemesi durumunda, taşınmazları üzerinde kısıtlılık bulunan maliklerin katlanmaları gereken sürenin belirsiz olması ve mülkiyetin getirdiği haklardan yararlanamaması ya da yararlanmasının zorlaşması, maliklere aşırı bir külfet yüklenmesine sebep olmaktadır. Malikler açısından bu kadar önem arz eden ve hazırlanması yasal bir zorunluluk olan imar programlarıı hazırlamayan ya da var olan programlara uymayan belediyeler hakkında yasada tanımlanmış herhangi bir yaptırım bulunmamaktadır. Ülkemizde 2011 (URL-2), 2014 (URL-3) ve 2016 y1lı verilerine (URL-4) göre, belediyelerin yalnızca yarısında imar programı bulunmaktadır. Ayrıca farklı yıllarda yapılan sorgulamaya göre belediyelerin imar programı yapma eğilimleri değişmemektedir.

İmar programlarındaki aksamanın sebebi, belediyelerin etaplar halinde de olsa 5 yıl içerisinde imar planının tamamını gerçekleştirecek finansmana ve diğer kaynaklara sahip olmamasıdır. Benzer şekilde ilgili diğer idareler de planda edinimi kendi sorumluluğunda olan hizmet alanlarını kamulaştıracak kaynaklara sahip değildir. Ülkemizde planların gerçekleştirilmesinde kullanılabilecek yöntemlerin tamamı, belirli bir finansman ve emek gerektirmektedir. İdarelerin bu amaçla kullanabilecekleri üç temel yöntem bulunmaktadır. Bu yöntemler: kamulaştırma yoluyla yapılan uygulamalar, maliklerin isteği üzerine parsel bazında yapılan uygulamalar ile arsa ve arazi düzenlemesidir. Kamulaştırma yoluyla yapılan uygulamalar; yüksek uygulama ön maliyeti, mülkiyetin devamlılığının sağlanamaması ve eşitlik bakımından sorunlar barındırmaktadır. İsteğe bağlı uygulamalar ise bütüncül olmaktan daha çok parsel bazında gerçekleşmekte ve yoğun kentsel alan gereksinimini karşılamada yetersiz kalmaktadır. Bu sebeplerle düzenlemede gerçekleşen değer artışı karşıllı̆̆ında, umumi hizmet alanlarının uygulamaya katılan maliklerden toprak kesintisiyle edinimini esas alan arsa ve arazi düzenlemesi yöntemi, arazi yönetimi açısından en verimli yöntemdir.

3194 sayılı İmar Kanunu'nun 18'inci maddesine dayanan arsa ve arazi düzenlemesi, 2020 yılında yapılan değişikliğe kadar, düzenleme bölgesinin \%40'ına kadar olan genel hizmet alanlarının, maliklerden bedelsiz toprak kesintisi ile edinimini; \%40’1 aşan durumlarda ise aşan kısmın kamulaştııılmasını ve kamusal hizmet alanlarının maliklere eşit oranlı dağıtılarak kamulaştırılmasını içermekteydi. Yöntem ile tüm genel hizmet alanları bedelsiz edinilirken kamusal hizmet alanlarının edinimi ise uzun yıllara yayılmaktaydı. Yöntemde 04.07.2019 tarihli ve 7181 sayılı Kanun'un 9'uncu maddesiyle yapılan değişiklikle maksimum Düzenleme Ortaklık Pay Oranı (DOPO) \%45'e çıkarılmışıı. Ayrıca ayrım olmaksızın tüm hizmet alanlarının 22.02.2020 tarihinde yayımlanan Arazi ve Arsa Düzenlemeleri Hakkında Yönetmelik ile belirlenen sıralamaya bağlı olarak edinilmesi ve \%45 oranının üzerindeki alanların 5 yıl içerisinde kamulaştırılmak üzere maliklere tahsis edilmesi düzenlenmiştir. Yöntem, her ne kadar donatı alanlarının Kanun'da belirtilen oran kadarının bedelsiz toprak kesintisi ile 
edinimini öngörmesi gibi diğer yöntemlere göre önemli bir avantaja sahip olsa da 2014 (URL-3) ve 2016 (URL-4) yılı verilerine göre idareler tarafindan tercih edilmemektedir (Tablo 1).

Tablo 1: Belediyenin 2014 ve 2016 yıllarında imar uygulamaları kapsamında kullandıkları yöntemlerin dağıımı

\begin{tabular}{ccccccc}
\hline Uygulama Tercihi & \multicolumn{2}{c}{ Kamulaştırma } & Arsa ve Arazi Düzenlemesi & \multicolumn{2}{c}{ İsteğe Bağlı Uygulama } \\
\hline Anket Yılı & $\mathbf{2 0 1 4}$ Yılı & $\mathbf{2 0 1 6}$ Yılı & $\mathbf{2 0 1 4}$ Yılı & $\mathbf{2 0 1 6}$ Yılı & $\mathbf{2 0 1 4}$ Yılı & $\mathbf{2 0 1 6}$ Yılı \\
\hline Büyükşehir İlçe Belediyeleri & $\% 26$ & $\% 28$ & $\% 34$ & $\% 34$ & $\% 40$ & $\% 38$ \\
\hline İl Belediyeleri & $\% 28$ & $\% 32$ & $\% 36$ & $\% 33$ & $\% 36$ & $\% 35$ \\
\hline İlçe Belediyeleri & $\% 24$ & $\% 26$ & $\% 32$ & $\% 30$ & $\% 44$ & $\% 43$ \\
\hline Belde Belediyeleri & $\% 24$ & $\% 22$ & $\% 31$ & $\% 28$ & $\% 45$ & $\% 50$ \\
\hline Tablo, URL-3 ve URL-4 'te yer alan veriler kullanılarak yazar tarafindan oluşturulmuştur. & & \\
\hline
\end{tabular}

Tablo 1 incelendiğinde, 2014 ve 2016 yıllarında farklı düzeydeki belediyelerin ancak üçte birinin imar uygulaması kapsamında arsa ve arazi düzenlemesi yöntemini kullandıkları ve ağırlıklı olarak malik ya da temsilcileriyle yapılan pazarlıklara dayanan isteğe bağlı uygulamaları kullandıkları görülmektedir (Bayındırlık ve İskân Bakanlığı, 2009). Ayrıca teknik personel ve bütçe olanakları daha kısıtlı olan (URL-4) ilçe ve belde belediyelerinin neredeyse yarısında temel imar uygulama yöntemi, isteğe bağlı uygulamalardır. Buna ek olarak yıllar içerisinde idarelerin kamulaştırma yöntemini kullanma oranları artmakta iken arsa ve arazi düzenlemelerinin kullanımı azalmaktadır.

$\mathrm{Bu}$ verilerin işaret ettiği durumun temel sebebi, idarelerin bütüncül bir uygulamanın masraflarını karşılamaktan kaçınmalarıdır. İdareler, bu kapsamda isteğe bağlı uygulama yaparak hizmet alanlarını, maliklere verilecek imar haklarının karşılığında bedelsiz, ancak uzun sürede edinmeyi tercih etmektedir. Bir hizmet alanının özel bir önem arz etmesi ya da hızlı bir şekilde gerçekleştirilmesi gereken durumlarda ise diğer bir araç olarak kamulaştırma ile kısa bir sürede bu alanlar sağlanabilmektedir. Ancak idareler tarafından benimsenen bu kentleşme yaklaşımı, malikler bakımından sakıncalıdır. Bu yaklaşımla bazı malikler, bir imar parseline denk gelerek imar hakkına sahip olabilmektedir. Ancak bazı malikler, herhangi bir imar parseli oluşturamayacak şekilde tamamıyla ya da kısmen umumi hizmet alanlarında kalabilmektedir. Bu taşınmazlar için isteğe bağlı uygulama avantajlı olmayacağından malikler, genellikle kamulaştırma ya da arsa ve arazi düzenlemesini beklemek zorunda bırakılmaktadır. Bu sebeple ülkemizde imar planlarının uygulanması ve maliklerin taşınmazları üzerinde kısıtlılık oluşturan umumi hizmet alanlarının edinimi, idarelerin maddi olanaksızlıkları sebebiyle geniş zamana yayılmaktadır. Bu durum da maliklerin taşınmazları üzerinde belirsiz bir kısıtlılık oluşturmaktadır. Türkiye genelinde 416 belediyenin, 1932 ile 1990 yılları arasında yapılan imar planlarıyla; geri kalan 1526 belediyenin ise 1990 yılı ve sonrası yapılan imar planlarıyla 2011 yılında uygulama yaptıkları görülmektedir (URL-2). Yalnız bu veriye bağlı olarak bile imar planlarıyla taşınmazları üzerindeki tasarrufu kısıtlanan maliklerin imar planlarının uzun yıllar boyunca gerçekleştiril(e)memesi sebebiyle taşınmazları üzerindeki belirsiz kısıtlılık durumunun kaldırılmasını bekledikleri açıktır. Mülkiyet hakkından yoksun bırakma biçimindeki bu kısıtlamalar, hedeflenen kamu yararı ile malikin bireysel yararı arasında gözetilmesi gereken adil dengeyi bozmaktadır. İmar planı ile kamu hizmetine ayrılmış ya da tasarruf hakkı kısıtlanmış taşınmazların uzun süre kamulaştırılmaması veya imar hakkı tanımlanmaması sebebiyle "kamulaştırmasız el atma" durumu oluşmaktadır. İçtihatta sıklıkla, bir taşınmaza eylemli olarak el atıp tamamen veya kısmen kullanılmasına engel olunması ile imar uygulaması sonucu taşınmazı hukuken kullanmaya engel sınırlamalar getirilmesi arasında, sonucu itibariyle bir fark bulunmadığı ve mülkiyet hakkının sınırlandırılması sonucunu doğurduğu belirtilmektedir. İdarelerin, imar planının yürürlüğe girmesi ile planın gerçekleştirilmesi için imar programını hazırlamakla yükümlü olmalarına rağmen; pasif ve suskun kalarak, imar programına almayarak planları fiilen hayata geçirmemesi, kamulaştırma ya da takas ile çözüm üretmemesi yargı tarafından kamulaştırmasız el atmanın varlığı için yeterli görülmektedir.

Kamulaştırmasız el atma sorununun temel sebebi, imar programlarının ve imar planlarının, idarelerin planda yer alan hizmet 
alanlarının edinimini sağlayacak finansmana ve diğer kaynaklara sahip olmaması sebebiyle uzun yıllar gerçekleştirilememesidir. Ancak bu durum, kanun koyucu tarafından sorunun çözümüne ilişkin çıkarılan kanunların çoğunda göz ardı edilerek sorunun çözümü yerine çözümün ertelenmesi benimsenmiştir. Süreç içinde kanun koyucunun mülkiyet hakkını kısıtlayıcı benzer yaklaşımları, sıklıkla yüksek mahkeme kararlarına konu olmuş, bazı hükümler iptal edilirken bazı hükümler günümüze kadar yürürlükte kalmıştır. Bu durum, kamulaştırmasız el atma kavramını düzenleyen hükümlerin bir karmaşa haline gelmesine ve farklı dönemlerde el atmanın niteliğine ve tarihine göre farklılaşmasına sebep olmuştur. Kamulaştırmasız el atma kavramının tüzel gelişimini oluşturan bu süreç, maliklerin mülkiyet haklarını ve idareleri doğrudan etkilemiştir. Bu makalede, kamulaştırmasız el atma kavramının tüzel gelişimini oluşturan kanun düzenlemelerinin ve yargı kararlarının bir süreç içerisinde tanımlanarak incelenmesi amaçlanmaktadır. Bu amaca ulaşmak üzere izleyen bölümde, 1956 ile 2020 yılları arasında kamulaştırmasız el atma kavramının tüzel gelişimini oluşturan kanun düzenlemeleri ve yargı kararları, süreç içinde farklı hükümlerin geçerli olduğu dönemlere ayrılmıştır. Her bir dönem; geçerli olan hükümler, kanun koyucunun kamulaştırmasız el atma sorununa olan yaklaşımı, yüksek yargı makamlarının duruşu, maliklerin mülkiyet hakkına ve idarelere olan etkileri ve elde edilen sonuçlar bakımından irdelenmiştir. Makalenin son bölümünde kamulaştırmasız el atma kavramının tüzel gelişimi özetlenmiş, el atmanın niteliğine bağlı olarak geçerli olan güncel hükümler ile bu hükümlere dair değerlendirmeler verilmiştir.

\section{Kamulaştırmasız El Atma Kavramının Tüzel Gelişimi}

Kamulaştırmasız el atma kavramı, 1950’lerden günümüze kadar farklı kanun düzenlemeleri ve yargı kararları ile şekillenmiş ancak yaşanan sorunlar halen tamamıyla çözümlenememiş̧ir. Sürecin başlangıcında yalnızca fiili el atmalar, kamulaştırmasız el atma olarak değerlendirilirken; 2010 yılından itibaren hukuki el atmalar da kamulaştırmasız el atma olarak kabul edilmiştir. Kanun koyucu tarafından kamulaştırmasız el atma ve hukuki el atma sorunlarına dair birçok yasal düzenleme yapılmıştır. Bu düzenlemeler, genellikle kamulaştırmasız el atılan taşınmazların kapsamının daraltılması, kamulaştırılmış sayılması, dava hakkının kısıtlanması ya da ötelenmesi gibi mülkiyet hakkının ölçüsüz biçimde sınırlandırılmasına ve hakkın özüne dokunarak kullanılamaz hâle gelmesine yol açacak niteliktedir. Süreç içerisinde bu nitelikteki düzenlemeler, yargı kararları ile iptal edilmesine rağmen kanun koyucu iptal kararlarına karşı benzer hükümleri içeren yeni kanunlar çıkararak direnmiştir. Bu durum, kamulaştırmasız el atma kavramını düzenleyen hükümlerin, süreç içinde bir karmaşa haline gelmesine ve farklı dönemlerde el atmanın niteliğine ve tarihine göre farklılaşmasına sebep olmuştur.

Çalışmanın bu bölümünde, 1956 ile 2020 yılları arasında kamulaştırmasız el atma kavramının tüzel gelişimi, süreç içinde farklı hükümlerin geçerli olduğu sekiz döneme ayrılmıştır. Her bir dönem; geçerli olan hükümler, kanun koyucunun kamulaştırmasız el atma sorununa olan yaklaşımı, yüksek yargı makamlarının duruşu, maliklerin mülkiyet hakkına ve idarelere olan etkileri ve elde edilen sonuçlar bakımından irdelenmiştir. Bu bağlamda kamulaştırmasız el atma kavramının ilk kez kabul edildiği ve tüzel gelişiminin başlangıcını oluşturan dönem, aşağıda verilmiştir.

\subsection{Sürecin Başlangıç Dönemi: Kamulaştırmasız El Atma Kavramının Kabulü}

Kamulaştırmasız el atma kavramı, ilk kez Yargıtay İçtihadı Birleştirme Büyük Genel Kurulu'nun (YİBBGK) 16.05.1956 tarih ve E: 1956/1, K: 1956/6-7 sayılı İçtihadı Birleştirme Kararında (URL-5) ele alınarak esasa bağlanmıştır. Bu kararda taşınmazına kamulaştırmasız el konulan kimsenin, ilgili kamu tüzel kişisi aleyhine herhangi bir hak düşürücü süre olmaksızın el atmanın önlenmesi davası açabileceği gibi, dava tarihindeki bedelini ve tazminat verilmesini de isteyebileceği belirtilmiştir. Böylelikle kamulaştırmasız el atma kavramı ilk kez düzenlenmiştir. Bu karar sonrasında, 09.10.1956 tarihinde 6830 sayılı İstimlâk Kanunu yürürlüğe girerek idarelerin kamulaştırma işlemlerindeki kuralları belirlenmiş ancak kamulaştırmasız el atılan taşınmazlara ilişkin herhangi bir hükme yer verilmemiş̧ir. 
Kanun koyucu tarafından, kamulaştırmasız el atılan taşınmazlara ilişkin bir istisna olarak belirli bir süre içinde kamulaştırması yapılmayan taşınmazların, kamu adına tescilini içeren 12.01.1961 tarihli ve 221 sayılı Amme Hükmi Şahıslar veya Müesseseleri Tarafından Fiilen Amme Hizmetlerine Tahsis Edilmiş Gayrimenkuller Hakkındaki Kanun düzenlenmiştir. Bu kanun ile 6830 sayılı İstimlak Kanunu’nun yürürlüğe girdiği 09.10.1956 tarihine kadar geçen sürede kamulaştırma amacına yönelik olarak el atılan taşınmazlar, tahsis olarak nitelendirilerek kamulaştırılmış sayılmıştır. Bu taşınmazlar hakkında el atmanın önlenmesi ile tazminat davası açılamayacağı düzenlenmiştir. Düzenlemede maliklere tanınan bedel dava hakkı ise Kanun'un yürürlüğe girdiği tarihten itibaren 2 yıllık hak düşürücü süreye tabi tutulmuştur. Kanun'un yürürlüğe girmesinden önce açılan ve devam eden davalarda ise bu hükümler geçerli kılınarak tüm davaların yalnızca bedel davası olarak sonuçlandırılması hükme bağlanmıştır. Ancak Kanun’da yer alan tazminat davası açılamayacağı hükmü, Anayasa Mahkemesi'nin 17.01.2008 tarihli ve E: 2004/25, K: 2008/42 sayılı kararı (URL-6) ile iptal edilmiştir. Bu kararla, 221 sayılı Kanun'un öngördüğü tarihten önce kamulaştırılmış sayılan taşınmazlara ilişkin tazminat davası açılabilmesinin de önü açılmıştır.

Böylelikle, kamulaştırmasız el atma davalarının başlangıcını 6830 sayılı İstimlak Kanunu’nun yürürlüğe girdiği 09.10.1956 tarihi oluşturmaktadır. Bu tarihten önceki el atmalar ise 221 sayılı Kanun hükümlerince kamulaştırılmış sayılmaktadır. 221 sayılı Kanun, her ne kadar bir istisna olarak düzenlenmiş olsa da 08.11.1983 tarihinde yürürlüğe giren 2942 sayılı Kamulaştırma Kanunu'nun geçici 4’üncü maddesinde de yer alarak kapsamına giren tazminat davalarıyla beraber yürürlüğü devam etmektedir.

$\mathrm{Bu}$ dönemde kamulaştırmasız el atma kavramına ilişkin farklı hükümlerin geçerli olduğu zaman aralıkları ile bu zaman aralıklarında el atmanın niteliğine ve tarihine bağlı olarak maliklere tanınan dava hakları ve ilgili koşullar Tablo 2'de verilmiştir.

Tablo 2: Kamulaştırmasız el atmaya ilişkin 16.05.1956 - 08.11.1983 tarihleri arasında geçerli hükümler

\begin{tabular}{|c|c|c|c|c|}
\hline \multicolumn{5}{|c|}{ Kamulaştırmasız El Atmaya İlişkin Farklı Hükümlerin Geçerli Olduğu Dönemler } \\
\hline & \multirow{2}{*}{$\begin{array}{l}\text { Zaman Aralığı: } \\
\text { El Atma Tarihi: }\end{array}$} & \multirow{2}{*}{$\begin{array}{c}16.05 .1956^{(1)}-12.01 .1961^{(2)} \text { Arası } \\
\text { Tüm El Atmalar } \\
\end{array}$} & \multicolumn{2}{|c|}{ 12.01.1961 - 08.11.1983 ${ }^{(3)}$ Arası } \\
\hline & & & 09.10.1956 ${ }^{(4)}$ Öncesi & 09.10.1956 Sonrası \\
\hline \multirow{3}{*}{$\begin{array}{l}\text { Fiili El } \\
\text { Atma }\end{array}$} & $\begin{array}{l}\text { Tazminat } \\
\text { Davası }\end{array}$ & Açılabilir & $\begin{array}{l}\text { Açılamaz } \\
\text { Mevcut davalar bedel } \\
\text { olarak sonuçlandırılır. }\end{array}$ & Açılabilir \\
\hline & $\begin{array}{l}\text { El Atmanın } \\
\text { Önlenmesi }\end{array}$ & Açılabilir & Açılamaz & Açılabilir \\
\hline & Bedel Davası & $\begin{array}{c}\text { Açılabilir } \\
\text { Dava tar. nitelikleri }\end{array}$ & $\begin{array}{c}\text { Açılabilir } \\
\text { Hak düş. süre: } 2 \text { yıl } \\
\text { El atma tar. nitelikleri }\end{array}$ & $\begin{array}{c}\text { Açılabilir } \\
\text { Dava tar. nitelikleri }\end{array}$ \\
\hline $\begin{array}{r}\text { Hukuki } \\
\text { El Atma }\end{array}$ & $\begin{array}{c}\text { Tazminat / } \\
\text { Bedel Davası }\end{array}$ & & Açılamaz & \\
\hline $\begin{array}{l}\text { (1) YIBBGG } \\
\text { (2) } 221 \text { say } \\
\text { (3) } 2942 \mathrm{sa} \text {. } \\
\text { (4) } 6830 \mathrm{sa} \text {. } \\
\text { (5) Anayasc }\end{array}$ & $\begin{array}{l}\text { X'nin E: } 1956 / 1 \text { ve K } \\
\text { ll Kanun'un yürürlü } \\
\text { yılı Kanun'un yürürl } \\
\text { yılı Kanunu'nun yüri } \\
\text { Mahkemesi'nin } 17 .\end{array}$ & $\begin{array}{l}956 / 6-7 \text { sayılı İçtihadı Birleştirme Karc } \\
\text { girdiği tarih. } \\
\text { e girdiği tarih. } \\
\text { üğe girdiği tarih. } \\
2008 \text { tarihli ve E: } 2004 / 25, K: 2008 / 42\end{array}$ & $\begin{array}{l}\text { tarihi. } \\
\text { kararıly "açılabilir" }\end{array}$ & \\
\hline
\end{tabular}

Tablo 2'de özetlenen bu dönem içerisinde yalnızca fiili el atmalar, kamulaştırmasız el atma olarak kabul edilerek maliklere tanınan hakları düzenleyen, farklı hükümlerin geçerli olduğu iki zaman aralığı öne çıkmıştır. Bunlardan ilki, YİBBGK'nin E: 1956/1 ve K: 1956/6-7 sayılı kararının yürürlüğe girdiği 16.05.1956 tarihi ile başlayıp, 221 sayılı Kanun’un yürürlüğe girdiği 12.01.1961 tarihi ile sonlanmıştır. Bu zaman aralığında, kamulaştırmasız el atma kavramının tüzeye girmesini sağlayan YİBBGK kararı, maliklere fiili el atma kapsamında kabul edilebilir bir çözüm sağlamıştır. Bu karara göre hak düşürücü süre olmaksızın maliklere tazminat, ecri misil, el atmanın önlenmesi ve bedel davası açma hakkı tanınmış; açılacak 
davalarda ise taşınmazların dava tarihindeki değerinin esas alınması kabul edilmiştir. Ancak bu çözüm ile maliklere tanınan haklar, kanun koyucu tarafindan benimsenmemiştir. Bu dönemde çıkarılan 221 sayılı Kanun ile farklı hükümlerin geçerli olduğu ikinci zaman aralığı oluşmuştur. Bu zaman aralığı içerisinde el atma tarihine bağlı olan farklı hükümler getirilmiştir. $\mathrm{Bu}$ bağlamda, 09.10.1956 tarihinden önce fiilen el atılan taşınmazlar, kamulaştırmasız el atma yerine tahsis olarak kabul edilerek maliklerin karşılığı olmaksızın taşınmazlarını kaybetmesi düzenlenmiştir. Taşınmazlarına 09.10.1956 tarihinden sonra fiilen el atılan maliklerin ise tazminat, ecri misil ve el atmanın önlenmesi davası açmaları engellenerek yalnızca bedel davası açabilmeleri ve devam eden davaların bedel olarak sonuçlandırılması kararlaştırılmıştır. Açılacak bedel davalarında, 2 yıllık hak düşürücü süre ve taşınmazların el atma tarihindeki niteliklerinin esas alınması düzenlenmiştir. Değerin hesabında taşınmazın hangi tarihteki niteliklerinin esas alınacağı, maliklerin taşınmazlarının karşılığını almasında belirleyicidir. Bu bağlamda YİBBGK kararı, taşınmazın dava tarihinde el değiştirdiğini kabul ederek dava tarihindeki niteliklerinin esas alınmasını öngörmekteyken; kanun koyucu, el atma tarihindeki niteliklerin esas alınması ile değerin görece düşük hesaplanmasını benimsemiştir. El atma tarihi ile dava tarihi arasındaki sürenin uzun olması, iki farklı yaklaşıma bağlı olarak belirlenen değerin birbirinden farklı olmasına ve maliklerin beklentilerinin karşılanamamasına sebep olacaktır.

$\mathrm{Bu}$ zaman aralığı içerisinde geçerli hükümler, kamulaştırmasız el atma sorununun çözümü yerine maliklerin dava haklarının kısıtlanması, hak düşürücü süre ile el atılan taşınmazların bedelsiz ediniminin sağlanması ve bunun mümkün olmaması durumunda ise ödenecek bedellerin düşürülmesi amacını taşımaktadır. 221 sayılı Kanun'un yürürlüğe girmesi ile fiili el atmaya ilişkin geçerli olan bu hükümler, 2942 sayılı Kamulaştırma Kanunu'nun yürürlüğe girdiği 08.11.1983 tarihine kadar uygulanmıştır.

\subsection{Sayılı Kamulaştırma Kanunu Dönemi}

Kamulaştırmasız el atma kavramına ilişkin 08.11.1983 tarihli ve 2942 sayılı Kamulaştırma Kanunu'nun en önemli düzenlemesi, 38'inci maddesiyle kamulaştırmasız el atma davalarının açılabilmesini, taşınmaza el atma tarihinden başlamak üzere yirmi yıl olarak sınırlayan hak düşürücü süre tanımlamasıdır. Ancak düzenleme ile kamulaştırmasız el atma davalarına getirilen hak düşürücü süre, kamulaştırmasız el atma sebebiyle açılacak bedel davalarında zaman aşımının uygulanmayacağını hüküm altına alan 16.05.1956 tarih ve E: 1956/1, K: 1956/6-7 sayılı Yargıtay İçtihadı Birleştirme Kararı (URL-5) ile çatışmaktadır. Ancak bu hüküm, Anayasa'nın geçici 15'inci maddesinin kısıtlaması sebebiyle dava edilememiştir. Bu durum, Anayasa'nın geçici 15'inci maddesinde 03.10.2001 tarihli ve 4709 sayılı Türkiye Cumhuriyeti Anayasası'nın Bazı Maddelerinin Değiş̧tirilmesi Hakkında Kanun'un 34'üncü maddesiyle yapılan düzenlemeye kadar değişmemiş̧tir. Bu düzenleme sonrası ilgili hüküm yargıya taşınarak Anayasa Mahkemesi'nin 10.04.2003 tarihli, E: 2002/112 ve K: 2003/33 sayılı kararıyla (URL-7) iptal edilmiştir. İptal kararının gerekçesinde, yapılan düzenlemenin Anayasa'da belirtilen kamulaştırma ilkelerine aykırı olduğu ve yirmi yıllık hak düşürücü sürenin, taşınmaz malikinin her türlü dava açma hakkının engellenmesi ve taşınmazın hiçbir karşlık ödenmeden idareye geçmesi bakımından mülkiyet hakkının sınırlandırılmasını aşan ve hakkın özünü zedeleyen bir durum olarak tanımlanmıştır. İptal kararının yürürlüğe girmesinden sonra, 20 yılı aşan kamulaştırmasız el atma davalarında iki farklı yoruma dayanan uygulama farklılı̆̆ ortaya çıkmıştır. (URL5: 5. HD, E: 2004/5533, K: 2004/7414, T: 28.06.2004; 5. HD, E: 2004/3072, K: 2004/4829, T: 20.04.2004; 5. HD, E: 2002/4716, K: 2002/7834, T: 02.04.2002; 5. HD, E: 2004/11053, K: 2005/682, T: 03.02.2005; 5. HD, E: 2005/9543, K: 2005/9747, T: 22.09.2005, 5. HD, E: 2005/1958, K: 2005/2672, T: 15.03.2005, 5. HD, E: 2003/11875, K: 2003/13650, T: 19.11.2003, 5. HD, E: 2003/012198, K: 2003/13680, T: 19.11.2003, 5. HD, E: 2003/12198, K: 2003/13680, T: 19.11.2003; 5. HD, E: 2003/13035, K: 2004/949, T. 12.02.2004; 5. HD, E: 2003/013035, K: 2003/949, T: 12.02.2004). Bu bağlamda, içtihattaki bazı davalarda, Anayasa Mahkemesi'nin iptal kararının (URL-7) yirmi yıllık hak düşürücü süreyi ortadan kaldırdığı için kamulaştırmasız el koyma sebebiyle her zaman dava açılabileceği kabul edilmiştir. Ancak bazı davalarda, hak düşürücü sürenin Anayasa Mahkemesi'nin iptal kararının (URL-7) yürürlüğe girdiği tarihe kadar geçerli olduğu ve el atma 
tarihinden itibaren yirmi yıl içinde dava açılmamışsa iptal kararının yürürlüğe girdiği tarihten sonra da dava açılamayacağı kabul edilmiştir. Bu iki farklı yoruma dayanan içtihat kararları beraber değerlendirildiğinde, Anayasa Mahkemesi'nin iptal kararının (URL-7) yürürlüğe girişinin (04.11.2003) 20 yıl öncesini ifade eden 04.11.1983 tarihinden sonra kamulaştırmasız el atılan taşınmazlara ilişkin tazminat ve el atmanın önlenmesi davaları açılmasında herhangi bir engel bulunmamaktadır. Ancak içtihat kararlarındaki yorum farklılı̆ğ sebebiyle bazı davalarda, 04.11.1983 tarihinden önce kamulaştırmasız el atılan taşınmazlara ilişkin tazminat ve el atmanın önlenmesi davaları açılamayacağı yönünde kararlar alınmıştır.

Bu dönemde kamulaştırmasız el atma kavramına ilişkin farklı hükümlerin geçerli olduğu zaman aralıkları ile bu zaman aralıklarında el atmanın niteliğine ve tarihine bağlı olarak maliklere tanınan dava hakları ve ilgili koşullar Tablo 3'te verilmiştir.

Tablo 3: Kamulaştırmasız el atmaya ilişkin 08.11.1983 - 30.06.2010 tarihleri arasında geçerli hükümler

\begin{tabular}{|c|c|c|c|c|c|c|}
\hline \multicolumn{7}{|c|}{ Kamulaştırmasız El Atmaya İlişkin Farklı Hükümlerin Geçerli Olduğu Dönemler } \\
\hline \multirow{2}{*}{\multicolumn{2}{|c|}{$\begin{array}{l}\text { Zaman Aralığı: } \\
\text { El Atma Tarihi: }\end{array}$}} & \multirow{2}{*}{\multicolumn{2}{|c|}{$\begin{array}{cc}08.11 .1983^{(1)}-04.11 .2003^{(2)} \text { Arası } \\
09.10 .1956^{(4)} & 09.10 .1956 \\
\text { Öncesi }^{\text {Ön }} & \text { Sonrası }\end{array}$}} & \multicolumn{3}{|c|}{ 04.11.2003 - 30.06.2010 ${ }^{(3)}$ Arası } \\
\hline & & & & $\begin{array}{c}09.10 .1956 \\
\text { Öncesi }\end{array}$ & $\begin{array}{c}09.10 .1956- \\
04.11 .1983^{(6)} \text { Arası }\end{array}$ & $\begin{array}{c}04.11 .1983 \\
\text { Sonrası } \\
\end{array}$ \\
\hline \multirow{3}{*}{$\begin{array}{l}\text { Fiili El } \\
\text { Atma }\end{array}$} & $\begin{array}{c}\text { Tazminat } \\
\text { Davası }\end{array}$ & $\begin{array}{c}\text { Açılamaz }^{(5)} \\
\text { Mevcut davalar } \\
\text { bedel olarak } \\
\text { sonuçlandırılır. }\end{array}$ & $\begin{array}{c}\text { Açılabilir } \\
\text { Hak düş. süre: } \\
20 \text { yıl }\end{array}$ & $\begin{array}{c}\text { Açılamaz }^{(5)} \\
\text { Mevcut davalar } \\
\text { bedel olarak } \\
\text { sonuçlandırılır. }\end{array}$ & $\begin{array}{c}\text { Açılabilir } \\
\text { Hak düş. süre: } \\
\text { yok }^{(7)} / 20 \text { yıl }^{(8)}\end{array}$ & Aç1labilir \\
\hline & $\begin{array}{c}\text { El Atmanın } \\
\text { Önlenmesi }\end{array}$ & Açılamaz & $\begin{array}{c}\text { Açılabilir } \\
\text { Hak düş. süre: } \\
20 \text { yıl }\end{array}$ & Açılamaz & $\begin{array}{c}\text { Açılabilir } \\
\text { Hak düş. süre: } \\
\text { yok }^{(7)} / 20 \mathrm{yll}^{(8)}\end{array}$ & Açılabilir \\
\hline & $\begin{array}{c}\text { Bedel } \\
\text { Davası }\end{array}$ & $\begin{array}{c}\text { Açılabilir } \\
\text { Hak düş. süre: } \\
2 \text { yıl } \\
\text { El atma tar. } \\
\text { nitelikleri } \\
\end{array}$ & $\begin{array}{c}\text { Açlabilir } \\
\text { Hak düş. süre: } \\
20 \text { yıl } \\
\text { El atma tar. } \\
\text { nitelikleri } \\
\end{array}$ & $\begin{array}{c}\text { Açlabilir } \\
\text { Hak düş. süre: } \\
2 \text { y1l } \\
\text { El atma tar. } \\
\text { nitelikleri } \\
\end{array}$ & $\begin{array}{c}\text { Açılabilir } \\
\text { Hak düş. süre: } \\
\text { yok }^{(7)} / 20 \text { yıl } \\
\text { El atma tar. } \\
\text { nitelikleri } \\
\end{array}$ & $\begin{array}{l}\text { Açılabilir } \\
\text { Dava tar. } \\
\text { nitelikleri }\end{array}$ \\
\hline $\begin{array}{c}\text { Hukuk } \\
\text { El Atma }\end{array}$ & $\begin{array}{c}\text { Tazminat / } \\
\text { Bedel Davası }\end{array}$ & & & Açılamaz & & \\
\hline \multicolumn{7}{|c|}{ 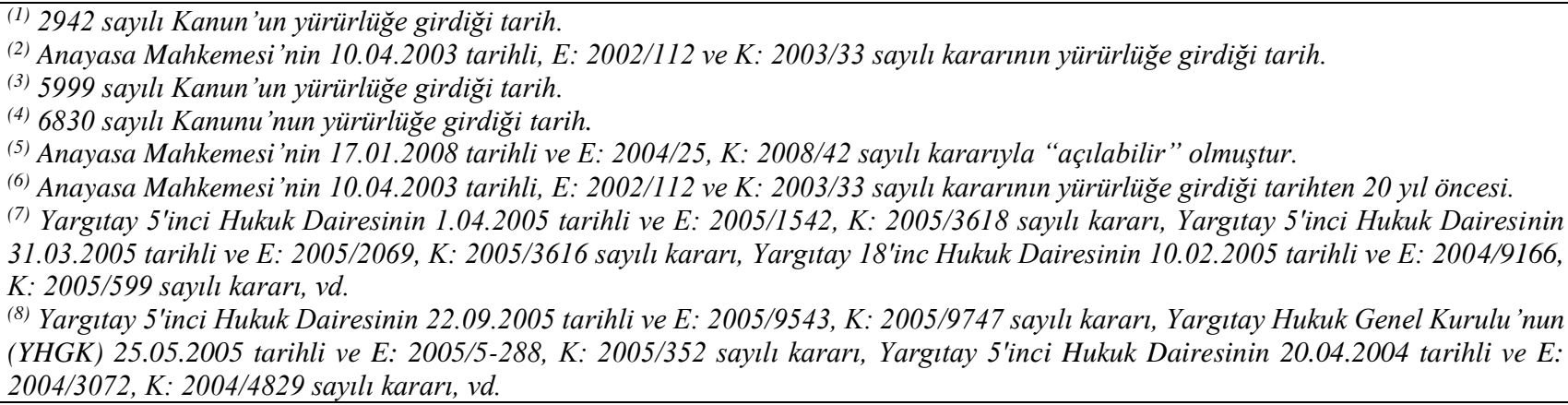 } \\
\hline
\end{tabular}

Tablo 3 'te özetlenen bu dönem içerisinde yalnızca fiili el atmalar, kamulaştırmasız el atma olarak kabul edilmiş ve maliklere tanınan hakları düzenleyen, farklı hükümlerin geçerli olduğu iki zaman aralığı öne çıkmıştır. Bunlardan ilki, 2942 sayılı Kanun'un yürürlüğe girdiği 08.11.1983 tarihi ile başlayıp, Anayasa Mahkemesi’nin 10.04.2003 tarihli, E: 2002/112 ve K: 2003/33 sayılı kararının yürürlüğe girdiği 04.11.2003 tarihiyle sonlanmıştır. Bu zaman aralığında, el atma tarihine bağlı olarak 09.10.1956 öncesi fiili el atmalar, 221 sayılı Kanun uyarınca tahsis olarak kabul edilmiştir. Taşınmazlarına 09.10.1956 sonrası el atılan maliklerin ise açacağı tüm davalara 2942 sayılı Kanun uyarınca 20 yıllık hak düşürücü süre getirilmiştir. Kanun koyucu tarafından hak düşürücü sürenin 20 yıl seçilmesinin sebebi, kazandırıcı zamanaşımı süresi olarak ifade edilmiştir. Bu zaman aralığında birçok davanın 20 yıllık sürenin geçmesi gerekçe gösterilerek reddedilmesi, fiilen el atılan taşınmazların bedelsiz olarak idarelerce edinimini sağlayarak maliklerin haklarının ihlaline sebep olmuştur. Buna ek olarak bedel davalarında, taşınmazların el atma tarihindeki niteliklerinin esas alınması ile ödenecek bedellerin düşürülmesi 
amaçlanmıştır. $\mathrm{Bu}$ hükümler, kamulaştırmasız el atılan taşınmazların karşılığı ödenmeden hak düşürücü süre ile kamu tarafından edinimini içermesi ve dönemin siyasi koşulları sebebiyle düzenlemenin iptali için yaklaşık 20 yıl boyunca dava açılamaması sebebiyle yaşanan problemlerin ve mağduriyetlerin artmasına sebep olmuştur. Bu zaman aralığında maliklerin haklarını aramalarını engelleyen hükümlerin, Anayasa Mahkemesi’nin 10.04.2003 tarihli, E: 2002/112 ve K: 2003/33 sayılı kararı ile iptal edilmesi, farklı hükümlerin geçerli olduğu ikinci zaman aralığının başlangıcını oluşturmuştur. Bu zaman aralığı içerisinde de el atma tarihine bağlı olarak 09.10.1956 öncesi fiili el atmalar, 221 sayılı Kanun uyarınca tahsis olarak kabul edilmiştir. 09.10.1956 tarihinden başlayarak Anayasa Mahkemesi’nin iptal kararının 20 yıl öncesini ifade eden 04.11.1983 tarihine kadar gerçekleşen fiili el atmalarda ise iki farklı yoruma dayanan uygulama farklılığı ortaya çıkmıştır. Bu hukuki boşluk döneminde 20 yıllık hak düşürücü süreye dâhil olan maliklerin hakları, Anayasa Mahkemesi kararına rağmen korunamamış; fiilen el atılan birçok taşınmaz, idareler adına bedelsiz olarak tescil edilerek büyük hak kayıpları oluşmuştur. Buna ek olarak 20 yıllık hak düşürücü süresi dolmamış fiili el atmalarda taşınmazların el atma tarihindeki nitelikleri esas alınarak ödenecek bedellerin düşürülmesi sağlanmıştır. Anayasa Mahkemesi'nin iptal kararı, 04.11.1983 tarihinden sonra taşınmazlarına fiili el atılan maliklerin 16.05.1956 tarihli Yargıtay İçtihadı Birleştirme Kararı uyarınca hak düşürücü süre olmaksızın tazminat, ecri misil, el atmanın önlenmesi ve bedel davası açabilmesini mümkün hale getirmiş ve açılan dava sayısını arttırmıştır. Ayrıca bedel davalarında taşınmazların dava tarihindeki niteliklerinin esas alınması ile bir önceki zaman aralığına göre daha yüksek bedellere hükmedilmesi sağlanmıştır.

2942 sayılı Kanun'un yürürlüğe girmesiyle başlayan bu dönemde fiili el atmaya ilişkin farklı zaman aralığında geçerli olan hükümler, 5999 sayılı Kanun'un yürürlüğe girdiği 30.06.2010 tarihine kadar uygulanmıştır.

\subsection{Sayılı Kamulaştırma Kanunu'nda Değişiklik Yapılmasına Dair Kanun Dönemi}

Anayasa Mahkemesi'nin iptal kararı (URL-7) ile ortaya çıkan karışıklığın ve uygulamadaki farklılığın önlenmesi amacıyla 30.06.2010 tarihli ve 5999 sayılı Kamulaştırma Kanunu’nda Değişiklik Yapılmasına Dair Kanun ile 2942 sayılı Kamulaştırma Kanunu'na geçici 6'ncı madde eklenmiştir. Eklenen bu madde, sabit bir zaman aralığını kapsayan istisnai düzenlemeleri içermektedir. Bu zaman aralığının başlangıcı olarak 6830 sayılı İstimlak Kanunu'nun yürürlüğe girdiği 09.10.1956 tarihi seçilmiştir. Bunun temel sebebi, 6830 sayılı Kanun’un yürürlüğe girdiği tarihten önce gerçekleşen kamulaştırmasız el atılan taşınmazlara ilişkin 12.01.1961 tarihli ve 221 sayılı Kanun’un düzenlenmiş olması ve bu Kanun’un 2942 sayılı Kamulaştırma Kanunu'nun geçici 4'üncü maddesinde de yer alarak halen yürürlükte olmasıdır. Eklenen bu maddenin geçerli olduğu zaman aralığının başlangıcı olarak seçilen 09.10.1956 tarihinden önce kamulaştırmasız el atılan taşınmazlar, 221 sayılı Kanun uyarınca kamulaştırılmış sayılacak ve bu taşınmazlar için el atmanın önlenmesi davası açılamayacaktır. 221 sayılı Kanun'da yer alan tazminat davası açılamayacağı hükmü, Anayasa Mahkemesi’nin 17.01.2008 tarihli ve E: 2004/25, K: 2008/42 sayılı kararı (URL-6) ile iptal edildiğinden kamulaştırılmış sayılan taşınmazlara ilişkin tazminat davası açılabilmektedir.

Eklenen bu maddenin geçerli olduğu zaman aralığının bitişi olarak ise 04.11.1983 tarihi seçilmiştir. Bu tarih, kamulaştırmasız el atma davalarının açılabilmesini yirmi yıl olarak sınırlayan 2942 sayılı Kanun'un 38'inci maddesini iptal eden Anayasa Mahkemesi'nin 10.04.2003 tarihli, E: 2002/112 ve K: 2003/33 sayılı kararının (URL-7) yürürlüğe girdiği tarihin 20 y1l öncesini ifade etmektedir. Düzenlemenin bitişi olarak seçilen bu tarihten sonra kamulaştırmasız el atılan taşınmazlara ilişkin tazminat ve el atmanın önlenmesi davaları açılmasında geçici 6’ncı maddenin yürürlüğe girdiği tarih itibari ile herhangi bir engel bulunmamaktadır. Bu sebeplerle 30.06.2010 tarihli ve 5999 sayılı Kamulaştırma Kanunu’nda Değişiklik Yapılmasına Dair Kanun ile 2942 sayılı Kamulaştırma Kanunu'na eklenen geçici 6’ncı maddenin kapsamı, 09.10.1956 ile 04.11.1983 tarihleri arasında kamulaştırmasız el atılan taşınmazlar olmuştur. Bu maddeye göre, bu zaman aralığında kamulaştırmasız el atılan taşınmaza ilişkin maliklerce el atmanın önlenmesi davası açılamamakla birlikte yalnızca tazminat talebinde 
bulunulması hâlinde, öncelikle uzlaşma yoluna gidilmesi ve uzlaşmanın oluşmaması durumunda dava açılabilmesi düzenlenmiştir.

Bu dönemde kamulaştırmasız el atma kavramına ilişkin farklı hükümlerin geçerli olduğu zaman aralıkları ile bu zaman aralıklarında el atmanın niteliğine ve tarihine bağlı olarak maliklere tanınan dava hakları ve ilgili koşullar Tablo 4'te verilmiştir.

Tablo 4: Kamulaştırmasız el atmaya ilişkin 30.06.2010 - 15.12.2010 tarihleri arasında geçerli hükümler

\begin{tabular}{|c|c|c|c|c|}
\hline \multicolumn{5}{|c|}{ Kamulaştırmasız El Atmaya İlişkin Farklı Hükümlerin Geçerli Olduğu Dönemler } \\
\hline & Zaman Aralı̆̆ı: & & 30.06.2010 ${ }^{(1)}-15.12 .2010^{(2)}$ Arası & \\
\hline & El Atma Tarihi: & 09.10.1956 ${ }^{(3)}$ Öncesi & 09.10.1956 - 04.11.1983(4) Arası & 04.11.1983 Sonrası \\
\hline \multirow{3}{*}{$\begin{array}{c}\text { Fiili El } \\
\text { Atma }\end{array}$} & Tazminat Davası & Açılabilir ${ }^{(5)}$ & $\begin{array}{c}\text { Açılabilir } \\
\text { Ön koşul: Uzlaşma } \\
\text { Hak düş. süre: } 3 \text { ay }^{(7)}\end{array}$ & Açılabilir \\
\hline & $\begin{array}{l}\text { El Atmanın } \\
\text { Önlenmesi }\end{array}$ & Açılamaz & Açılamaz & Açılabilir \\
\hline & Bedel Davası & $\begin{array}{c}\text { Açılabilir } \\
\text { Hak düş. süre: } 2 \text { yıl } \\
\text { El atma tar. nitelikleri }\end{array}$ & $\begin{array}{l}\text { Açılabilir } \\
\text { Ön koşul: Uzlaşma } \\
\text { Hak düş. süre: } 3 \text { ay }^{(7)} \\
\text { El atma tar. nitelikleri }\end{array}$ & $\begin{array}{c}\text { Açılabilir } \\
\text { Dava tar. nitelikleri }\end{array}$ \\
\hline $\begin{array}{l}\text { Hukuki } \\
\text { El Atma }\end{array}$ & $\begin{array}{c}\text { Tazminat / } \\
\text { Bedel Davası }\end{array}$ & & Açılamaz & \\
\hline \multicolumn{5}{|c|}{ 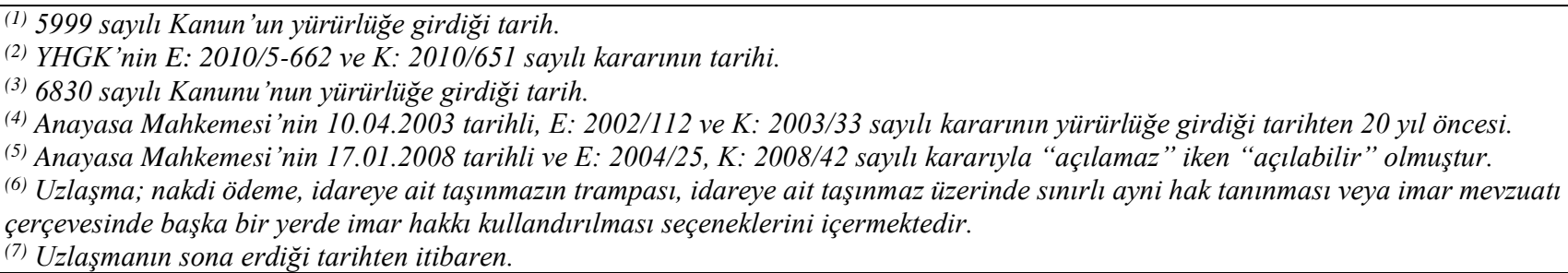 } \\
\hline
\end{tabular}

Tablo 4'te özetlenen bu dönem içerisinde yalnızca fiili el atmalar, kamulaştırmasız el atma olarak kabul edilmiş ve maliklere tanınan hakları düzenleyen hükümlerin geçerli olduğu tek bir zaman aralığı öne çıkmıştır. Bu zaman aralığı, 5999 sayılı Kanun'un yürürlüğe girdiği 30.06.2010 tarihiyle başlayıp, YHGK'nin E: 2010/5-662 ve K: 2010/651 sayılı kararının yürürlüğe girdiği 15.12.2010 tarihi ile sonlanmıştır. Bu tarihler arasında, el atma tarihine bağlı olarak 09.10.1956 öncesi fiili el atmalar, 221 sayılı Kanun uyarınca tahsis olarak kabul edilmiştir. Bu tarihten başlayarak 04.11.1983 tarihine kadar gerçekleşen fiili el atmalarda ise 5999 sayılı Kanun ile geçici 6’ncı maddesi uyarınca istisnai hükümler geçerli olmuştur. Bu istisnai hükümler, bir taraftan bir önceki dönemde 20 yıllık hak düşürücü süre sebebi ile davaları reddedilen maliklere çözüm seçeneği sunarken diğer taraftan da maliklerin çözüme ulaşmalarını zorlaştırmıştır. Bu hükümlere göre maliklerin el atmanın önlenmesi davası açması engellenmiş; tazminat, ecri misil ve bedel davası açmaları ise uzlaşma ön koşuluna ve hak düşürücü süreye tabi tutulmuştur. Bu bağlamda, maliklerle nakdi ödeme üzerine uzlaşılması durumunda; bütçeden ayrılacak yüzde iki payın kullanılması, bu payın yeterli olmaması durumunda ödemenin taksitli yapılması, taksitlendirmede süre sınırlamasının olmaması maliklerin uzlaşma ile hızlı bir çözüme ulaşmalarını zorlaştırmıştır. Ayrıca idarelerin mal, hak ve alacaklarının haczedilememesi hükmü getirilerek idarelere koruma sağlanmıştır. Bu koruma ile maliklerin, idarelerce tazminat, bedel ya da nakdi uzlaşma taksiti gibi ödemelerin yapılmasını beklemek dışında bir seçeneği kalmamıştır. Malik ile idare arasında uzlaşma olmaması durumunda ise maliklerin üç ay içerisinde sadece tazminat (bedel) davası açabilmesi düzenlenmiştir. Bu davalarda taşınmazların el atma tarihindeki niteliklerinin esas alınması ile ödenecek bedellerin de düşürülmesi sağlanmıştır. $\mathrm{Bu}$ hükümler, kanun koyucunun problemin çözümünden daha çok mahkemelerin iş yükünün azaltılmasını, el atılan taşınmazların hak düşürücü süre ile bedelsiz edinimini, kısıtlanmış hükümlerle ve görece düşük bedellerle edinilen taşınmazların sayısının arttırılmasını amaçladığını göstermektedir. Bu istisnai hükümler, 04.11.1983 tarihine kadar fiilen el 
atılan taşınmazlar için geçerli olup, bir önceki dönemde olduğu gibi 04.11 .1983 tarihinden sonra el atılan taşınmazlara ilişkin 16.05.1956 tarihli Yargıtay İçtihadı Birleştirme Kararı uyarınca hak düşürücü süre olmaksızın tazminat, ecri misil, el atmanın önlenmesi ve bedel davası açabilmesi yürürlükten kalmıştır.

5999 sayılı Kanun'un yürürlüğe girmesiyle başlayan bu dönemde fiili el atmaya ilişkin hükümler, 6111 sayılı Kanun'un yürürlüğe girdiği 25.02.2011 tarihine kadar; hukuki el atmaya ilişkin hükümler ise YHGK'nin E: 2010/5-662, K: 2010/651 sayılı kararının alındığ 15.12.2010 tarihine kadar uygulanmıştır.

\subsection{Yargitay Hukuk Genel Kurulu'nun 15.12.2010 tarihli ve E: 2010/5-662, K: 2010/651 Sayılı Kararı Dönemi}

2010 yılının sonuna kadar hem tüzede ve hem de içtihat kararlarında benimsenen genel kanı, yalnızca fiili el atmaların kamulaştırmasız el atma olarak değerlendirilmesidir. Bu kapsamda birçok yargı kararında, taşınmazın imar planında kullanımını kısıtlayıcı bir fonksiyonda kalması kamulaştırmasız el atma olarak kabul edilmemiştir. Kamulaştırmasız el atmanın varlığı için taşınmaza fiilen el atılarak kullanımının yasaya aykııı şekilde tamamen ortadan kaldırılması ve bu durumun kalıcı olması gerektiği benimsenmiştir (URL-5: Yargıtay 5'inci Hukuk Dairesinin 17.03.2008 tarihli, E: 2008/446, K: 2008/3092 sayılı ve 18.03.1983 tarihli, E: 1983/2515, K: 1983/2637 sayll kararlar1, YHGK'nin 29.09.2004 tarihli, E: 2004/5-450, K: 2004/454 sayılı ve 07.11.2007 tarihli, E: 2007/5-805, K: 2007/826 sayılı kararları). Ancak tüzede ve içtihat kararlarında benimsenen kamulaştırmasız el atma kavramının kapsamı, YHGK'nin 15.12.2010 gün ve 2010/5-662 esas, 2010/651 sayılı kararıyla (URL-5) genişletilmiştir. Kararda, fiilen el atılmamış olsa bile imar planı ile kamu hizmetine ayrılmış ya da tasarruf hakkı kısıtlanmış taşınmazların uzun süre kamulaştırılmaması veya imar hakkı tanımlanmamış olması "kamulaştırmasız el atma" olarak değerlendirilmiştir. Kararda, bir taşınmaza eylemli olarak el atıp tamamen veya kısmen kullanılmasına engel olunması ile imar uygulaması sonucu taşınmazı hukuken kullanmaya engel sınırlamalar getirilmesi arasında sonucu itibariyle bir fark bulunmadığı ve mülkiyet hakkının sınırlandırılması sonucunu doğurduğu belirtilmiştir. Kararda ayrıca idarelerin, 3194 sayılı İmar Kanunu'nun 10’uncu maddesinin birinci fikrası hükmü uyarınca, imar planının yürürlük tarihinden itibaren en geç 3 ay içerisinde planın tatbiki için 5 yıllık imar programını hazırlamakla yükümlü oldukları belirtilmiştir. İdarelerin, imar planlarını uzun yıllar imar programına almayarak fiilen hayata geçirmemesiyle yükümlüklerini yerine getirmemeleri ve kamulaştırma ya da takas işlemleri ile çözüm üretmeyerek pasif ve suskun kalmaları kamulaştırmasız el atmanın varlığı için yeterli bulunmuştur. Böylelikle "hukuki el atma" olarak nitelendirilen bu durumlarda, maliklerin kamulaştırmasız el atma sebebiyle tazminat davası açılabilmesi mümkün hale gelmiştir.

Bu dönemde kamulaştırmasız el atma kavramına ilişkin farklı hükümlerin geçerli olduğu zaman aralıkları ile bu zaman aralıklarında el atmanın niteliğine ve tarihine bağlı olarak maliklere tanınan dava hakları ve ilgili koşullar Tablo 5 ’te verilmiştir.

Tablo 5'te özetlenen bu dönem içerisinde fiili el atmalara ilişkin herhangi bir değişiklik olmamış ve 5999 sayılı Kanun'un yürürlüğe girmesiyle geçerli olan hükümler, 6111 sayılı Kanun'un yürürlüğe girdiği 25.02 .2011 tarihine kadar da yürürlükte kalmıştır. Bu dönemin en önemli unsuru, 3194 sayılı Kanun'un yürürlüğe girmesi ile başlayan hukuki el atma sorununun çözümüne ilişsin hükümlerin oluşmasıdır. 3194 sayılı Kanun öncesinde yürürlükte olan 6785 sayılı Kanun'da, imar planları ile kamu hizmetlerine ayrılan yerler hakkında dört yıllık imar programında olanların süresi içerisinde, olmayanların ise maliklerin idareye başvurmalarından itibaren beş yıl içerisinde kamulaştırılmadığı takdirde inşaat haklarını kullanmalarına geçici olarak izin verilmekteydi. Maliklerin taşınmazlarındaki kısıtlılıkları belirli koşullar altında ortadan kaldıran bu hüküm, 3194 sayılı İmar Kanunu'nda yer almamış ve idarelerin imar planını gerçekleştirmede yükümlü oldukları belirtilmekle yetinilmiş̧ir. Bu yükümlülüklerini yerine getirmeyen idarelere karşı açılan davaların bir sonucu olarak da hukuki el atmalar, 2010 yılında kamulaştırmasız el atma olarak kabul edilmiştir. Bu karar, maliklerin kamulaştırmasız el atma sebebiyle 
tazminat/bedel davası açılabilmesini mümkün kılarak mağduriyetlerin giderilmesini sağlamıştır.

Tablo 5: Kamulaştırmasız el atmaya ilişkin 15.12.2010 - 25.02.2011 tarihleri arasında geçerli hükümler

\begin{tabular}{|c|c|c|c|c|}
\hline \multicolumn{5}{|c|}{ z El Atmaya İlişkin Farklı Hükümlerin Geçerli Olduğu Dönemler } \\
\hline & Zaman Aralığı: & & 5.12.2010 ${ }^{(1)}-25.02 .2011^{(2)}$ Arası & \\
\hline & El Atma Tarihi: & 09.10.1956 ${ }^{(3)}$ Öncesi & 09.10.1956-04.11.1983(4) Arası & 04.11.1983 Sonrası \\
\hline \multirow{3}{*}{$\begin{array}{c}\text { Fiili El } \\
\text { Atma }\end{array}$} & Tazminat Davası & Açılabilir & $\begin{array}{c}\text { Açılabilir } \\
\text { Ön koşul: Uzlaşma } \\
\text { Hak düş. süre: } 3 \mathrm{ay}^{(6)} \\
\end{array}$ & Açılabilir \\
\hline & $\begin{array}{l}\text { El Atmanın } \\
\text { Önlenmesi }\end{array}$ & Açılamaz & Açılamaz & Açılabilir \\
\hline & Bedel Davası & $\begin{array}{c}\text { Açılabilir } \\
\text { Hak düş. süre: } 2 \text { yıl } \\
\text { El atma tar. nitelikleri }\end{array}$ & $\begin{array}{c}\text { Açılabilir } \\
\text { Ön koşul: Uzlaşma } \\
\text { Hak düş. süre: } 3 \text { ay }^{(6)} \\
\text { El atma tar. nitelikleri }\end{array}$ & $\begin{array}{c}\text { Açılabilir } \\
\text { Dava tar. nitelikleri }\end{array}$ \\
\hline $\begin{array}{l}\text { Hukuki } \\
\text { El Atma }\end{array}$ & $\begin{array}{c}\text { Tazminat / } \\
\text { Bedel Davası }\end{array}$ & & Açılabilir & \\
\hline \multicolumn{5}{|c|}{$\begin{array}{l}\text { (1) YHGK'nin E: 2010/5-662 ve K: 2010/651 sayılı kararının tarihi. } \\
\text { (2) 6111 sayılı Kanunu'nun yürürlüğe girdiği tarih. } \\
\text { (3) 6830 sayılı Kanunu'nun yürürlüğe girdiği tarih. } \\
\text { (4) Anayasa Mahkemesi'nin 10.04.2003 tarihli, E: 2002/112 ve K: 2003/33 sayılı kararının yürürlüğe girdiği tarihten } 20 \text { yıl öncesi. } \\
\text { (5) Uzlaşma; nakdi ödeme, idareye ait taşınmazın trampası, idareye ait taşınmaz üzerinde sinırlı ayni hak tanınmast veya imar mevzuatı } \\
\text { çerçevesinde başka bir yerde imar hakkı kullandırllması seçeneklerini içermektedir. } \\
\text { (6) Uzlaşmanın sona erdiği tarihten itibaren. }\end{array}$} \\
\hline
\end{tabular}

YHGK'nin 15.12.2010 tarihli ve E: 2010/5-662, K: 2010/651 sayılı kararı ile başlayan bu dönemde hukuki el atmaya ilişkin hükümler, 6487 sayılı Kanun’un yürürlüğe girdiği 11.06.2013 tarihine kadar; fiili el atmaya ilişkin hükümler ise bu dönemde değişmeyerek 6111 sayılı Kanunu'nun yürürlüğe girdiği 25.02.2011 tarihine kadar uygulanmıştır.

\subsection{Sayılı Bazı Alacakların Yeniden Yapılandırılması ile Sosyal Sigortalar ve Genel Sağlık Sigortası Kanunu ve Diğer Bazı Kanun ve Kanun Hükmünde Kararnamelerde Değişiklik Yapılması Hakkında Kanun Dönemi}

YHGK'nin hukuki el atmaları da kamulaştırmasız el atma olarak nitelendirilen kararı (URL-5) ile çözüm bulunamayan kamulaştırmasız el atma davaları, hukuki el atmaları da kapsayacak şekilde genişlemiştir. Kamulaştırmasız el atmanın kapsamının hukuki el atmaları da kapsayacak şekilde genişletilmesi karşısında, kanun koyucu tarafından bu taşınmazlara ilişkin istisnai hükümlerin geçerli olması düzenlenmiştir. Bu amaçla 25.02.2011 tarihli 6111 sayılı Bazı Alacakların Yeniden Yapılandırılması ile Sosyal Sigortalar ve Genel Sağlık Sigortası Kanunu ve Diğer Bazı Kanun ve Kanun Hükmünde Kararnamelerde Değişiklik Yapılması Hakkında Kanun'un geçici 2’nci maddesi ile 2942 sayılı Kamulaştırma Kanunu'nun geçici 6'ncı maddesinin, 04.11.1983 tarihinden sonraki kamulaştırmasız el koyma işlemlerini de kapsaması düzenlenmiştir. Böylelikle, 5999 sayılı yasa ile getirilen ve istisnai olarak 09.10.1956 ile 04.11.1983 tarihleri arasındaki kamulaştırmasız el atmaları kapsayan 2942 sayılı Kanun’un geçici 6'ncı maddesinin, on beş yıl süreyle geçerli olmak üzere, 09.10.1956 tarihinden sonraki kamulaştırmasız el atmaları da kapsaması düzenlenmiştir. Maddede ayrıca tazminat davalarında kullanılmak üzere idarelerin yıllık bütçelerinde, sermaye giderleri için öngörülen ödeneklerden yüzde beş pay ayrılması düzenlenmiştir. $\mathrm{Bu}$ düzenlemeyle 04.11.1983 tarihinden sonra kamulaştırmasız el atılan taşınmazlara ilişkin el atmanın önlenmesi davası açılabilmesi engellenerek, 09.10.1956 tarihinden 2026 yılına kadar kamulaştırmasız el atılan taşınmazlara ilişkin, öncelikle uzlaşma yoluna gidilmesi ve ancak uzlaşmanın oluşmaması durumunda sadece tazminat davası açılabilmesi düzenlenmiştir. Ancak Anayasa Mahkemesi'nin 01.11.2012 tarihli ve E: 2010/83, K: 2012/169 sayılı kararı (URL-8) ile 6111 sayılı Kanun'un geçici 2'nci maddesi, Anayasa'ya aykırı olması sebebiyle iptal edilmiştir. İptal gerekçesinde, geçmişe yönelik bazı mağduriyetlerin giderilmesi amacıyla çıkarılan ve istisnai nitelik taşıyan hükümlerin geleceğe yönelik olarak uygulanması halinde, kamulaştırma için Anayasa ve Kanun'da öngörülen güvencelerin etkisiz kalabileceği ve 2026 yılına kadar idarelerin kamulaştırma yerine kamulaştırmasız el atma yoluyla müdahalesine yol açaca ğı belirtilmiştir. Bu karar ile 
geçici 6’ncı maddenin kapsamı, tekrar 09.10.1956 ile 04.11.1983 tarihleri arasında kamulaştırmasız el atılan taşınmazlar olmuştur. Kararda (URL-8) ayrıca 5999 sayılı Kanun'un 1'inci maddesiyle 2942 sayılı Kanunu'na eklenen geçici 6'ncı maddenin 6'ncı fikrasının birinci cümlesinde yer alan “sadece” sözcüğü de Anayasa'ya aykırı bulunarak iptal edilmiştir. Böylelikle 09.10.1956'dan sonra kamulaştırmasız el atılan taşınmazlar için malikler tarafından tazminat davasının yanı sıra el atmanın önlenmesi davasının da açılabilmesi hükme bağlanmıştır. Ancak dava şartı olarak öncelikle idareye başvurularak uzlaşma talebinde bulunulması yürürlükte kalmıştır. Böylelikle 2942 ve 221 sayılı Kanunlara göre kamulaştırmasız el atılan taşınmaza ilişkin tazminat davası açılabilmesinde herhangi bir ön koşul bulunmazken 5999 sayılı Kanun ile getirilen düzenleme ile malik tarafından uzlaşma için başvuru yapılması şartı düzenlenmiştir. Düzenlemenin gerekçesinde, malik ile idare arasında uzlaşma sağlanabilmesi durumunda davaların azalacağı ve böylelikle mahkemelerin iş yükünün azaltılmasının amaçlandığı belirtilmiştir.

$\mathrm{Bu}$ dönemde kamulaştırmasız el atma kavramına ilişkin farklı hükümlerin geçerli olduğu zaman aralıkları ile bu zaman aralıklarında el atmanın niteliğine ve tarihine bağlı olarak maliklere tanınan dava hakları ve ilgili koşullar Tablo 6'da verilmiştir.

Tablo 6: Kamulaştırmasız el atmaya ilişkin 25.02.2011 - 11.06.2013 tarihleri arasında geçerli hükümler

\begin{tabular}{|c|c|c|c|c|c|c|}
\hline \multicolumn{7}{|c|}{ Kamulaştırmasız El Atmaya İlişkin Farklı Hükümlerin Geçerli Olduğu Dönemler } \\
\hline \multirow{2}{*}{\multicolumn{2}{|c|}{$\begin{array}{l}\text { Zaman Aralığı: } \\
\text { El Atma Tarihi: }\end{array}$}} & \multicolumn{2}{|c|}{$25.02 .2011^{(1)}-30.05 .2013^{(2)}$ Arası } & \multicolumn{3}{|c|}{ 30.05.2013-11.06.2013 ${ }^{(3)}$ Arası } \\
\hline & & $\begin{array}{l}09.10 .1956^{(4)} \\
\text { Öncesi } \\
\end{array}$ & $\begin{array}{c}\text { 09.10.1956 - } \\
\text { 30.05.2013 }{ }^{(5)} \text { Arası }\end{array}$ & $\begin{array}{c}\text { 09.10.1956 } \\
\text { Öncesi } \\
\end{array}$ & $\begin{array}{c}09.10 .1956- \\
04.11 .1983^{(6)} \text { Arası }\end{array}$ & $\begin{array}{c}04.11 .1983 \\
\text { Sonrası } \\
\end{array}$ \\
\hline \multirow{3}{*}{$\begin{array}{c}\text { Fiili El } \\
\text { Atma }\end{array}$} & $\begin{array}{c}\text { Tazminat } \\
\text { Davası }\end{array}$ & Aç1labilir & $\begin{array}{c}\text { Açılabilir } \\
\text { Ön koşul: Uzlaşma }{ }^{(7)} \\
\text { Hak düş. süre: } 3 \mathrm{ay}^{(8)}\end{array}$ & Aç1labilir & $\begin{array}{c}\text { Açılabilir } \\
\text { Ön koşul: Uzlaşma } \\
\text { Hak düş. süre: } 3 \mathrm{ay}^{(8)} \\
\end{array}$ & Aç1labilir \\
\hline & $\begin{array}{l}\text { El Atma } \\
\text { Önlenm }\end{array}$ & Açılamaz & Aç1lamaz & Açılamaz & Açılabilir & Aç1labilir \\
\hline & $\begin{array}{c}\text { Bedel } \\
\text { Davası }\end{array}$ & $\begin{array}{l}\text { Açılabilir } \\
\text { Hak düş. } \\
\text { süre: } 2 \text { yıl } \\
\text { El atma tar. } \\
\text { nitelikleri } \\
\end{array}$ & $\begin{array}{c}\text { Aç1labilir } \\
\text { Ön koşul: Uzlaşma }{ }^{(5)} \\
\text { Hak düş. süre: } 3 a y^{(6)} \\
\text { El atma tar. } \\
\text { nitelikleri } \\
\end{array}$ & $\begin{array}{l}\text { Açılabilir } \\
\text { Hak düş. } \\
\text { süre: } 2 \text { yıl } \\
\text { El atma tar. } \\
\text { nitelikleri } \\
\end{array}$ & $\begin{array}{c}\text { Açılabilir } \\
\text { Ön koşul: Uzlaşma } \\
\text { Hak düş. süre: } 3 \text { ay }^{(6)} \\
\text { El atma tar. } \\
\text { nitelikleri } \\
\end{array}$ & $\begin{array}{l}\text { Aç1labilir } \\
\text { Dava tar. } \\
\text { nitelikleri }\end{array}$ \\
\hline $\begin{array}{r}\text { Hukuki } \\
\text { El Atma }\end{array}$ & $\begin{array}{c}\text { Tazminat / } \\
\text { Bedel Davası }\end{array}$ & & & Aç1labilir & & \\
\hline \multicolumn{7}{|c|}{ 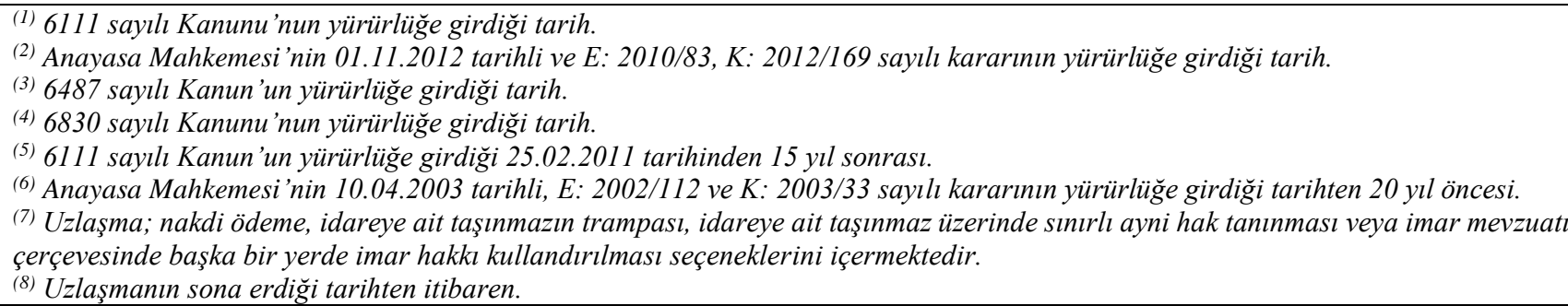 } \\
\hline
\end{tabular}

Tablo 6'da özetlenen bu dönem içerisinde, hukuki el atmalara ilişkin YHGK'nin 15.12.2010 tarihli ve E: 2010/5-662, K: 2010/651 sayılı kararı ile maliklere sağlanan haklarda herhangi bir değişiklik olmazken taşınmazlarına fiilen el atılan maliklerin haklarını kısıtlayan düzenlemeler yapılmıştır. Bu bağlamda, taşınmazlarına fiili el atılan maliklere tanınan hakları düzenleyen, farklı hükümlerin geçerli olduğu iki zaman aralığı öne çıkmıştır. Bunlardan ilki, 6111 sayılı Kanun’un yürürlüğe girdiği 25.02.2011 tarihi ile başlayıp Anayasa Mahkemesi’nin 01.11.2012 tarihli ve E: 2010/83, K: 2012/169 sayıl1 kararının yürürlüğe girdiği 30.05.2013 tarihiyle sonlanmıştır. Bu tarihler arasında el atma tarihine bağlı olarak 09.10.1956 öncesi fiili el atmalar, 221 sayılı Kanun uyarınca tahsis olarak kabul edilmiştir. 09.10.1956 tarihinden başlayarak 6111 sayılı Kanun’un yürürlüğe girdiği tarihten 15 yıl sonrasını ifade eden 25.02.2026 tarihine kadar gerçekleşen fiili el atmalarda ise 5999 sayılı Kanun ile getirilen geçici 6'ncı madde hükümlerinin 04.11.1983 tarihinden sonra da -25.02.2026 tarihine kadar- geçerli olması düzenlenmiştir. Böylelikle idarelere kamulaştırmadan daha cazip koşullara sahip bir edinim yolu düzenlenerek fiili el 
atmalar teşvik edilmiştir. Bu hükümler, hakları kısıtlanan maliklerin sayısını arttırmış; dava sayılarının uzlaşma ile azaltılmasını ve bunun mümkün olmadığı durumlarda ise davaların istisnai hükümlere göre sonuçlandırılmasını amaçlamıştır. Maliklerin haklarını geleceğe yönelik kısıtlayan bu hükümler, Anayasa Mahkemesi'nin 01.11.2012 tarihli ve E: 2010/83, K: 2012/169 sayılı kararı ile iptal edilmiştir. Böylelikle, iptal kararının yürürlüğe girdiği 30.05.2013 tarihi, farklı hükümlerin geçerli olduğu ikinci zaman aralığının başlangıcını oluşturmuştur. Bu zaman aralığında da 09.10.1956 öncesi fiili el atmalar, 221 sayılı Kanun uyarınca tahsis olarak kabul edilmiştir. Taşınmazlarına 09.10.1956 ile 04.11.1983 arası fiili el atılan maliklerin ise 5999 sayılı Kanun'un geçici 6'ncı maddesi uyarınca el atmanın önlenmesi, tazminat, ecri misil ve bedel davası açmaları uzlaşma ön koşuluna ve hak düşürücü süreye tabi tutulmuştur. Taşınmazlarına 04.11.1983 tarihinden sonra fiili el atılan maliklerin ise 16.05.1956 tarihli Yargıtay İçtihadı Birleştirme Kararı uyarınca hak düşürücü süre olmaksızın tazminat, ecri misil, el atmanın önlenmesi ve bedel davası açabilmesi mümkün olmuştur.

Bu dönem içerisinde YHGK'nin 15.12.2010 tarihli ve E: 2010/5-662, K: 2010/651 sayılı kararı ile taşınmazlarında hukuki el atılan maliklere sağlanan haklarda herhangi bir değişiklik olmazken; fiili el atmaya ilişkin farklı zaman aralıklarında geçerli olan hükümler, 6487 sayılı Kanunu’nun yürürlüğe girdiği 11.06.2013 tarihine kadar uygulanmıştır.

\subsection{Sayılı Bazı Kanunlar ile 375 Sayılı Kanun Hükmünde Kararnamede Değişiklik Yapılması Hakkında Kanun Dönemi}

Anayasa Mahkemesi’nin 6111 sayılı Kanun hükümlerini iptal eden kararı (URL-8), 22.02.2013 tarihli ve 28657 sayılı Resmi Gazete yayımlanarak 30.05.2013 tarihinde yürürlüğe gireceği belirtilmiştir. İptal kararlarının yürürlüğe giriş tarihinden hemen sonra, kanun koyucu tarafından 11.06.2013 tarihli ve 6487 sayılı Bazı Kanunlar ile 375 sayılı Kanun Hükmünde Kararnamede Değişiklik Yapılması Hakkında Kanun çıkarılmıştır. Kanun’un 21'inci maddesi ile Anayasa Mahkemesi'nin iptal ettiği 2942 sayılı Kamulaştırma Kanunu'nun geçici 6’ncı maddesi yeniden düzenlenmiş ve 22'nci maddesi ile geçici 7 'nci madde eklenmiştir.

6487 sayılı Kanun'un 21'inci maddesinin gerekçesinde, Anayasa Mahkemesi tarafından 2942 sayılı Kanun'un 2 farklı maddesinin iptaline ilişkin verilen kararlar öne sürülmüştür. Bunlardan ilki, taşınmaza el atma tarihinden başlamak üzere yirmi yıl hak düşürücü süre öngören 38'inci maddeyi iptal eden ve davalarda farklı uygulamalara sebep olan 10.04.2003 tarihli ve E: 2002/112, K: 2003/33 sayılı karardır (URL-7). Maddenin gerekçesinde ileri sürülen diğer iptal kararı ise 09.10.1956 ile 04.11.1983 tarihleri arasında kamulaştırmasız el atılan taşınmaza ilişkin öncelikle uzlaşma yoluna gidilmesi koşuluyla yalnızca tazminat davası açılabilmesi koşullarının, 04.11.1983 tarihinden sonra da uygulanmasını öngören geçici 6'ncı maddeyi iptal eden 01.11.2012 tarihli ve E: 2010/83, K: 2012/169 sayılı karardır (URL-8). Maddenin gerekçesinde, bu iki iptal kararının sonucu olarak ortaya çıkan sorunların çözümü ve uygulama tarihleri arasındaki farklılığın giderilmesi sunulmuştur. Ancak kanun koyucu tarafından yapılan düzenlemelerin özü incelendiğinde, 2942 sayılı Kamulaştırma Kanunu'nun geçici 6'ncı maddesinin 6487 sayılı Kanun'un 21'inci maddesiyle düzenlenen metni ile 5999 sayılı Kanun'un 1'inci maddesiyle düzenlenen metni arasında birkaç yeni madde düzenlenmesi haricinde büyük farklar bulunmamaktadır. 6487 sayılı Kanun ile geçici 6’ncı maddenin başlığı “Kamulaştırılmaksızın Kamu Hizmetine Ayrılan Taşınmazların Bedel Tespiti" olarak değiştirilmiş ve buna bağlı olarak metinde yer alan "tazminat" ve "tazminat davası" ifadeleri, "bedel" ve “bedel tespiti” olarak değiştirilmiştir. Değişen maddenin birinci fikrasında, ilk defa 5999 sayılı Kanun ile el atma davalarının ön koşulu olarak öne sürülen "uzlaşma” kavramı, daha net bir ifade kullanılarak "dava şartı" şeklinde ifade edilmiştir. 5999 sayılı Kanun ile yapılan düzenlemede, malikin müracaatı ile başlaması öngörülen uzlaşma sürecinin 6487 sayılı Kanun ile yapılan düzenlemede, idarenin daveti ile de başlatılabileceği belirtilmiştir. Uzlaşma sürecinde, iki Kanun ile yapılan düzenlemede de; nakdi ödeme, idareye ait taşınmazın trampası, idareye ait taşınmaz üzerinde sınırlı ayni hak tanınması veya imar mevzuatı çerçevesinde başka bir yerde imar hakkı kullandırılması gibi seçenekler sunulmuştur. Ancak 5999 sayılı Kanun 
ile yapılan düzenlemede, nakdi ödeme ilk seçenek olarak sunulmakta iken; 6487 sayılı Kanun ile yapılan düzenlemede, diğer seçeneklerin mümkün olmaması halinde nakdi ödeme yapılması düzenlenmiştir. Buna ek olarak, değerleme işlemlerinde taşınmazın el koyma tarihindeki niteliklerinin esas alınması öngörülmüştür. Bu değişikliğin gerekçesinde sürecin uzamasına bağlı olarak nüfus ya da kamu yatırımları gibi sebeplerle kamulaştırmasız el atılan taşınmazların değerinde meydana gelen artış ya da azalışların, ödenecek tazminat ya da bedelinin hesaplanmasında dikkate alınmamasının amaçlandığı belirtilmiştir. İki kanun metni arasındaki benzerliklerden bir tanesi de açılabilecek davalar hakkındadır. Bu kapsamda her ne kadar 5999 sayılı Kanun ile düzenlenen geçici 6'ncı maddede yer alan "sadece tazminat davası açılabilir" ifadesindeki "sadece" sözcüğü, Anayasa Mahkemesi’nin 01.11.2012 tarihli ve E:2010/83, K:2012/169 sayılı kararı (URL-8) ile iptal edilmiş olsa da 6487 sayılı Kanun ile düzenlenen geçici 6'ncı maddede aynı sonucu doğuracak şekilde "malik veya idare tarafindan bedel tespiti davası açılabilir" ifadesi ile yer alarak yeniden düzenlenmiştir. Böylelikle Anayasa Mahkemesi'nin iptal kararının (URL-8) uygulama olanağı kalmamış ve maliklerle uzlaşma sağlanamaması durumunda açılacak davaların yalnızca bedel tespitine yönelik olması düzenlenmiştir. Ancak Anayasa Mahkemesi'nin 13.11.2014 tarihli ve E: 2013/95, K: 2014/176 say1lı kararında (URL-9) bu değişiklik isim değişikliği olarak değerlendirilmiş ve tazminat davasının da açılabileceği belirtilmiştir. Ayrıca iki Kanun ile yapılan düzenlemelerde de dava açılması için 3 aylık süre öngörülmüştür.

6487 sayılı Kanun ile geçici 6'ncı maddede yapılan önemli düzenlemelerden biri de hukuki el atma ile ilgilidir. Daha önce YHGK'nin 15.12.2010 tarihli ve E: 2010/5-662, K: 2010/651 sayılı kararıyla (URL-5) ilk kez uygulama olanağı bulan hukuki el atma kavramı, 6487 sayılı Kanun ile geçici 6'ncı maddede yapılan düzenlemenin 10'uncu fikrasında, ilk mevzuat düzenlemesi olarak yer almıştır. Yapılan düzenlemede, uygulama imar planlarında umumi hizmetlere ve resmî kurumlara ayrılan veya ilgili kanunların uygulamasıyla tasarrufu kısıtlanan taşınmazlar hakkında, 03.05 .1985 tarihli ve 3194 sayılı İmar Kanunu'nda öngörülen idari başvuru ve işlemler tamamlandıktan sonra idari yargıda dava açılabileceği düzenlenmiştir. Düzenlemenin kapsamı, devam eden tüm davalar olarak belirlenmiştir. Kararı kesinleşen davalarda ise ödenmesi kesinleşen tazminatların ayrılan ödeneği aşması hâlinde, kanuni faiz uygulanarak eşit taksitlerle ödeneceği düzenlenmiştir. Bu kapsamda ayrıca idare tarafından nakdi ödeme yerine diğer uzlaşma yollarının da teklif edilebileceği ve Kanun'un uzlaşmaya ilişkin hükümlerine göre işlem yapılabileceği düzenlenmiştir.

Maddenin 12'nci fikrası ile 2981 sayılı Kanun hükümlerine göre yapılan imar uygulamalarından doğan ve ipotekle teminat altına alınanlar da dâhil olmak üzere her türlü alacak ve bedellerin borçlu idarelerce, kanuni faiz oranı uygulanmak suretiyle güncellenerek ilgililerine ödenmesi düzenlenmiştir. Yapılan bu düzenleme ile idarelerce takdir edilen bedellerin doğruluğunun maliklerce sorgulanması engellenmiş; değerin yalnızca kanuni faiz kullanılarak güncellenmesini içeren bir hesaplama yöntemi getirilmiştir. Maddenin 13'üncü fikrası ile 04.11.1983 tarihinden, düzenlemenin yürürlüğe girdiği 11.06.2013 tarihine kadar gerçekleşen kamulaştırmasız el atmalar da madde kapsamına alınmıştır. Ayrıca bu taşınmazlar hakkında açılan ve kesinleşmeyen davalar da kapsam içerisinde tutulmuştur. Yapılan bu düzenlemeyle 04.11.1983 ile 11.06.2013 tarihleri arasında gerçekleşen ve 11.06.2013 tarihinden önce açılan ve devam eden kamulaştırmasız el atma davalarında, bu fikra içeriğinde belirtilen hükümlerin uygulanması düzenlenmiștir. Kanun koyucu tarafindan yapılan bu düzenleme, madde gerekçesinde de belirtilen Anayasa Mahkemesi'nin 01.11.2012 tarihli ve E: 2010/83, K: 2012/169 say1lı iptal kararının (URL-8) ortaya çıkardığı sorunların çözümü olarak öngörülmüştür. Bu fikrayla, 6111 sayılı Kanun'da yapılan ve Anayasa Mahkemesi tarafindan iptal edilen düzenlemeye benzer şekilde, 09.10.1956 ile 04.11.1983 tarihleri arasında gerçekleşen bazı mağduriyetlerin giderilmesi amacıyla çıkarılan ve istisnai nitelik taşıyan hükümlerin geleceğe yönelik olarak -11.06.2013 tarihine kadar- uygulanması düzenlenmiştir. Böylelikle, Anayasa Mahkemesi’nin iptal kararının (URL-8) uygulanması, kararın yürürlüğe girmesinden önce yapılan yasal düzenlemeyle engellenerek benzer hükümler yürürlükte tutulmuş̧ur. 
6487 sayılı Kanun ile 2942 sayılı Kanun'da yapılan diğer bir düzenleme de geçici 7'nci maddenin eklenmesidir. Geçici 7'nci madde ile yürürlükte olmayan 6830 sayılı ve 2942 sayılı Kanun'ların 16 ve 17 'inci maddeleri uyarınca mahkemelerce idare adına hükmen tescil kararı verilen kamulaştırmalar ile halen devam eden davalar hakkında hükümler düzenlenmiştir. Bu kapsamda devam eden davalarda bu maddedeki hükümlerin uygulanması, hükmen tescil kararı verilen kamulaştırmalarda ise tüm kamulaştırma işlemlerinin tamamlanmış sayılması, hak ya da alacak talebinde bulunulamaması, kamulaştırma ya da bedele itiraz davası açılamaması hüküm altına alınmıştır. Maddenin gerekçesinde, kamulaştırmasız el atma sebebiyle 5999 sayılı Kanun ile 2942 sayılı Kanun'a eklenen geçici 6'ncı madde hükümlerince tazminat davaları açıldığı ancak bu davalarda, bazı taşınmazların artık yürürlükte olmayan kanun maddelerine göre kamulaştırmalarının tamamlandığının ve bedellerinin ödendiğinin mahkemelerce dikkate alınmadığı belirtilmiştir.

6487 sayılı Kanun ile yapılan düzenlemeyle getirilen geçici 6'ncı ve 7'nci maddelerde geçen birçok hükmün Anayasa'ya aykırı olduğu öne sürülerek Anayasa Mahkemesi’ne iptal davası açılmıştır. Anayasa Mahkemesi tarafından yapılan inceleme sonucunda, 6487 sayılı Kanun ile düzenlenen geçici 6'ncı maddenin 12'nci ve 13'üncü fikraları ile geçici 7'nci maddenin tamamı, Anayasa Mahkemesi'nin 13.11.2014 tarihli ve E: 2013/95, K: 2014/176 sayılı kararıyla (URL-9) iptal edilmiştir. İptal kararında, geçici 6'ncı maddenin 12'nci fikrasının içeriğinde, değer tespiti için benimsenen hesap yönteminin, idarece takdir edilen bedelin uygulama tarihi itibari ile doğruluğunun sorgulanmasını ve taşınmazın gerçek değerinin tespit edilmesini engellediği belirtilmiştir. Ayrıca kararda geçici 6'ncı maddenin 13'üncü fıkrası da Anayasa'ya aykırı bulunarak iptal edilmiştir. Bu fikranın iptal gerekçesi ile Anayasa Mahkemesi’nin 6111 sayılı Kanun'un geçici 2'nci maddesini iptal eden 01.11.2012 tarihli ve E:2010/83, K:2012/169 sayılı kararının (URL-8) iptal gerekçeleri aynıdır. Her iki yasal düzenleme de kanun koyucu tarafından geçmişe yönelik bazı mağduriyetlerin giderilmesi amacıyla çıkarılan ve istisnai nitelik taşıyan hükümlerin geleceğe yönelik olarak uygulanmasını içermeleri sebebiyle Anayasa’ya aykırı bulunmuştur. Böylelikle, 5999 sayılı Kanunla düzenlenen geçici 6'ncı maddenin kapsamını genişleten 6111 sayılı düzenlemenin Anayasa Mahkemesince iptal edilmesi üzerine, iptal kararını (URL-8) geçersiz kılmak üzere 6487 sayılı Kanunla düzenlenen geçici 6'ncı maddenin de ilgili hükmü iptal edilmiştir. Buna ek olarak 6487 sayılı Kanun ile düzenlenen geçici 7'nci madde hükmü de Anayasa'ya aykırı bulunarak iptal edilmiştir. Maddenin iptal kararının gerekçesinde, geçmişte malikten kaynaklanmayan sebeplerle usulsüz tebligatların geçerli kabul edilerek kamulaştırma işlemlerinin tamamlanmış sayılması ile maliklerin dava açma hakkının ortadan kaldırılması ve açılan davaların içeriğinin incelenmeden reddedilmesi Anayasa'ya aykırı bulunmuştur. Anayasa Mahkemesi'nin iptal kararı sonucunda, kamulaştırmasız el atılan taşınmazlar için geçici 6'ncı maddenin kapsamı, tekrar 09.10.1956 ile 04.11.1983 tarihleri arasında gerçekleşen kamulaştırmasız el atılan taşınmazlar olmuştur. Bu tarihten sonraki el atmalarda, 16.05.1956 tarihli ve E: 1956/1, K: 1956/6-7 sayılı içtihadı birleştirme kararı geçerlidir. Bu sebeple de maliklerin uzlaşmanın dava şartı olması, hak düşürücü sürenin varlığı ya da yalnızca tazminat davası açılabilmesi gibi şartlara bağlı olmaksızın el atmanın önlenmesi ve tazminat davası açabilmesi mümkündür.

$\mathrm{Bu}$ dönemde kamulaştırmasız el atma kavramına ilişkin farklı hükümlerin geçerli olduğu zaman aralıkları ile bu zaman aralıklarında el atmanın niteliğine ve tarihine bağlı olarak maliklere tanınan dava hakları ve ilgili koşullar Tablo 7'de verilmiştir.

Tablo 7'de özetlenen bu dönem içerisinde, hem fiili hem de hukuki el atmalara ilişkin hükümler düzenlenmiştir. Hukuki el atmalara ilişkin daha önce YHGK'nin 15.12.2010 tarihli ve E: 2010/5-662, K: 2010/651 sayılı kararı ile maliklere sağlanan ve istikrar kazanan haklar kısıtlanarak, devam eden ve açılacak tüm davalar ön koşula bağlanmıştır. Ayrıca ödemelerin ayrılan bütçe durumuna göre taksitli olarak yapılabilmesi, taksitlerin ödenmemesi durumunda idarelerin mal, hak ve alacaklarının haczedilememesinin hüküm altına alınması ile maliklerin, idarelerin ödeme yapmasını beklemek dışında herhangi bir çözüm yolu kalmamıştır. 
Tablo 7: Kamulaştırmasız el atmaya ilişkin 11.06.2013 - 07.09.2016 tarihleri arasında geçerli hükümler

Kamulaştırmasız El Atmaya İlişkin Farklı Hükümlerin Geçerli Olduğu Dönemler

\begin{tabular}{|c|c|c|c|c|c|c|c|}
\hline \multicolumn{8}{|c|}{ Kamulaştırmasız El Atmaya İlişkin Farklı Hükümlerin Geçerli Olduğu Dönemler } \\
\hline & \multirow{2}{*}{$\begin{array}{l}\text { Zaman Aralığı: } \\
\text { El Atma Tarihi: }\end{array}$} & \multicolumn{3}{|c|}{$11.06 .2013^{(1)}-13.09 .2015^{(2)}$ arası } & \multicolumn{3}{|c|}{ 13.09.2015-07.09.2016 ${ }^{(3)}$ arası } \\
\hline & & $\begin{array}{c}09.10 .1956 \\
\text { Öncesi }\end{array}$ & $\begin{array}{c}09.10 .1956- \\
11.06 .2013 \\
\text { Arası }\end{array}$ & $\begin{array}{c}11.06 .2013 \\
\text { Sonrası }\end{array}$ & $\begin{array}{l}09.10 .1956 \\
\text { Öncesi }\end{array}$ & $\begin{array}{c}09.10 .1956- \\
04.11 .1983^{(5)} \\
\text { Arası } \\
\end{array}$ & $\begin{array}{c}04.11 .1983 \\
\text { Sonrası }\end{array}$ \\
\hline \multirow{3}{*}{ Fiili El Atma } & $\begin{array}{c}\text { Tazminat } \\
\text { Davası }\end{array}$ & Açılabilir & $\begin{array}{l}\text { Açılabilir }^{(6)} \\
\text { Ön koşul: } \\
\text { Uzlaşma }^{(7)} \\
\text { Hak düş. } \\
\text { süre: } 3 \text { ay }^{(8)}\end{array}$ & Açılabilir & Açılabilir & $\begin{array}{c}\text { Açılabilir } \\
\text { Ön koşul: } \\
\text { Uzlaşma }^{(7)} \\
\text { Hak düş. } \\
\text { süre: } 3 \text { ay }^{(8)}\end{array}$ & Açılabilir \\
\hline & $\begin{array}{l}\text { El Atmanın } \\
\text { Önlenmesi }\end{array}$ & Açılamaz & Açılamaz & Açılabilir & Açılamaz & Açılabilir & Açılabilir \\
\hline & $\begin{array}{c}\text { Bedel } \\
\text { Davası }\end{array}$ & $\begin{array}{l}\text { Aç1labilir } \\
\text { Hak düş. } \\
\text { süre: } 2 \text { y1l } \\
\text { El atma tar. } \\
\text { nitelikleri }\end{array}$ & $\begin{array}{l}\text { Açllabilir } \\
\text { Ön koşul: } \\
\text { Uzlaşma } \\
\text { Hak düş. } \\
\text { Häre: } 3 \text { ay }{ }^{(8)} \\
\text { El atma tar. } \\
\text { nitelikleri }\end{array}$ & $\begin{array}{l}\text { Açılabilir } \\
\text { Dava tar. } \\
\text { nitelikleri }\end{array}$ & $\begin{array}{l}\text { Açılabilir } \\
\text { Hak düş. } \\
\text { süre: } 2 \text { yil } \\
\text { El atma tar } \\
\text { nitelikleri }\end{array}$ & $\begin{array}{l}\text { Açllabilir } \\
\text { Ön koşul: } \\
\text { Uzlaşma } \\
\text { Hak düş. } \\
\text { süre: } 3 \text { ay }^{(8)} \\
\text { El atma tar. } \\
\text { nitelikleri }\end{array}$ & $\begin{array}{l}\text { Açılabilir } \\
\text { Dava tar. } \\
\text { nitelikleri }\end{array}$ \\
\hline
\end{tabular}

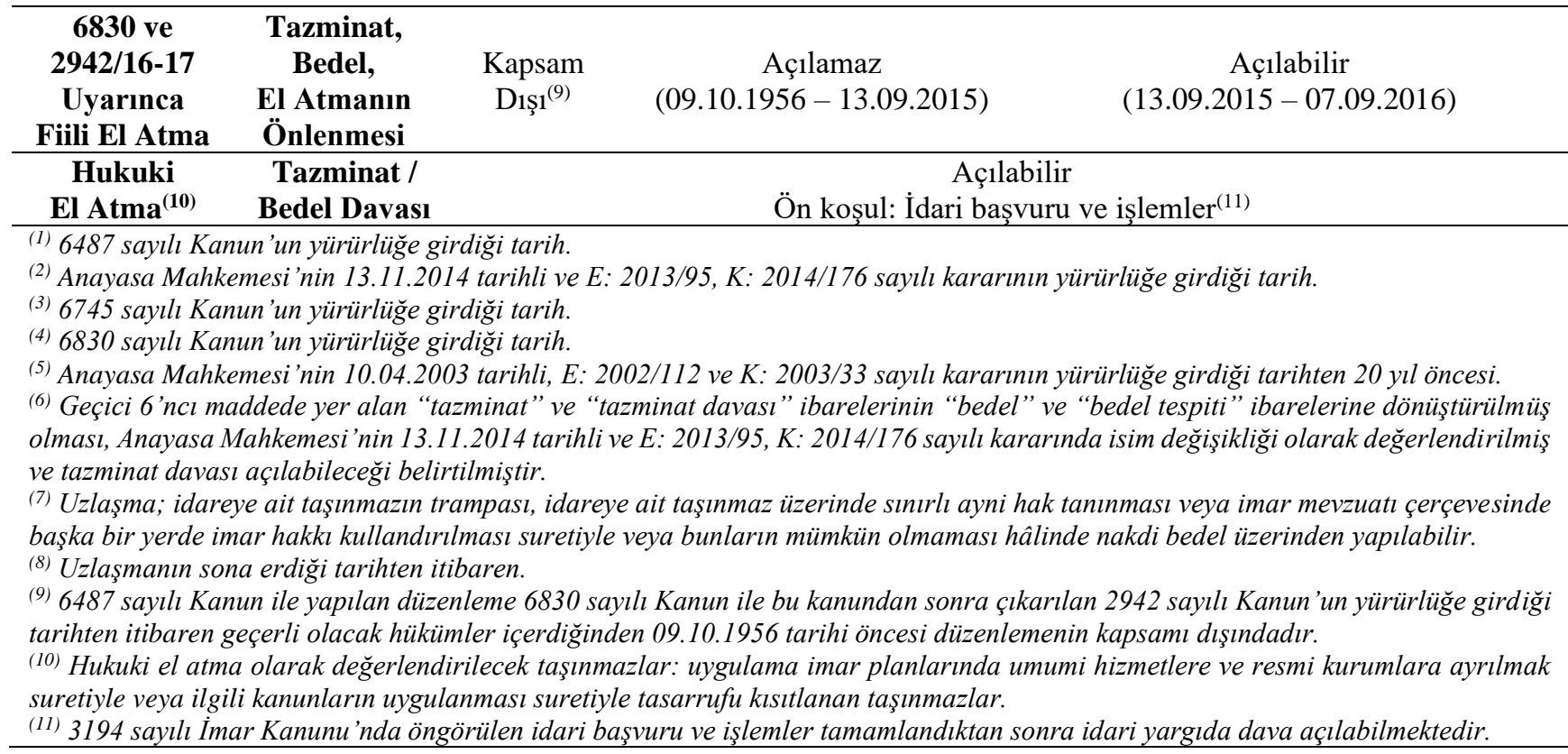

$\mathrm{Bu}$ dönemde fiili el atmalara ilişkin maliklere tanınan hakları düzenleyen, farklı hükümlerin geçerli olduğu iki zaman aralığı öne çıkmıştır. Bunlardan ilki, 6487 sayılı Kanunu'nun yürürlüğe girdiği 11.06 .2013 tarihi ile başlayıp Anayasa Mahkemesi'nin 13.11.2014 tarihli ve E: 2013/95, K: 2014/176 sayılı kararının yürürlüğe girdiği 13.09.2015 tarihiyle sonlanmıştır. Bu tarihler arasında, el atma tarihine bağlı olarak 09.10.1956 öncesi fiili el atmalar, 221 sayılı Kanun uyarınca tahsis olarak kabul edilmiştir. 09.10.1956 tarihinden başlayarak 6487 sayılı Kanun’un yürürlüğe girdiği 11.06.2013 tarihine kadar gerçekleşen fiili el atmalarda ise geçici 6'ncı maddede yer alan istisnai hükümlerin geçerli olması düzenlenmiştir. Yapılan bu düzenlemeyle kanun koyucunun maliklerin haklarını kısıtlamaya yönelik tavrı devam ederek maliklerin el atma davası açması engellenmiş; tazminat ve bedel davası açması ise uzlaşma ön koşuluna ve 3 aylık hak düşürücü süreye tabi tutulmuştur. 6487 sayılı Kanunu'nun yürürlüğe girdiği 11.06.2013 tarihinden sonra fiili el atılan taşınmazlara ilişkin herhangi bir hüküm getirilmediğinden, bu taşınmazlar için 16.05.1956 tarihli Yargıtay İçtihadı Birleştirme Kararı uyarınca hak düşürücü süre olmaksızın tazminat, ecri misil, el atmanın önlenmesi ve bedel davası açabilmesi yürürlükte kalmıştır. Bu zaman aralığında ayrıca mülga 6830 sayılı İstimlak Kanunu’nun 16 ve 17 'nci maddeleri ile 2942 sayılı Kanun'un mülga 16 ve 17 'nci maddeleri uyarınca usule uygun olmayan kamulaştırma işlemlerinin tamamlanmış sayılması ile maliklerin tüm dava hakları ellerinden alınmış ve hak arama özgürlükleri engellenmiştir. Maliklerin haklarını tamamen ortadan kaldıran ve 
k1sıtlayan bu hükümler, Anayasa Mahkemesi'nin 13.11.2014 tarihli ve E: 2013/95, K: 2014/176 sayılı kararı ile iptal edilmiştir. İptal kararının yürürlüğe girdiği 13.09.2015 tarihi, fiili el atmalara ilişkin farklı hükümlerin geçerli olduğu ikinci zaman aralığının başlangıcını oluşturmuştur. Bu bağlamda 09.10.1956 öncesi fiili el atmalar, 221 sayılı Kanun uyarınca tahsis olarak kabul edilmiştir. 09.10.1956 ile 04.11.1983 arası taşınmazlarına fiili el atılan maliklerin 5999 sayılı Kanun’un geçici 6'ncı maddesi uyarınca el atmanın önlenmesi, tazminat, ecri misil ve bedel davası açmaları uzlaşma ön koşuluna ve hak düşürücü süreye tabi tutulmuştur. 04.11.1983 tarihinden sonra fiili el atılan taşınmazlar hakkında ise 16.05.1956 tarihli Yargıtay İçtihadı Birleştirme Kararı uyarınca hak düşürücü süre olmaksızın tazminat, ecri misil, el atmanın önlenmesi ve bedel davası açılabilmesi hükümleri geçerli olmuştur. Buna ek olarak mülga 6830 sayılı İstimlak Kanunu'nun 16 ve 17 'nci maddeleri ile 2942 sayılı Kanun'un mülga 16 ve 17'nci maddeleri uyarınca taşınmazlarına el atılan maliklerin dava açabilmesi hüküm altına alınarak taşınmazlarının karşılıklarını tazmin edebilmesi mümkün hale gelmiştir.

$\mathrm{Bu}$ dönem içerisinde getirilmeye çalışılan kısıtlayıcı hükümler, idarelerin maddi ödemelerde sıkıntı yaşadığını ve kanun koyucunun bu bağlamdaki temel önleminin ödemelerin geciktirilmesi ile idarelerin kaynaklarının korunması olduğunu göstermektedir. Bu bağlamda, daha önce Anayasa Mahkemesi tarafından iptal edilen benzer hükümler, yeniden düzenlenerek idarelere zaman kazandırılması ve daha kısıtlayıcı hükümlere göre sonuçlandırılan davaların arttırılması amaçlanmıştır. Anayasa Mahkemesi'nin 13.11.2014 tarihli ve E: 2013/95, K: 2014/176 sayılı kararı ile fiili el atmalarda geçerli olan hükümler, kapsamlı bir değişiklik olmaksızın günümüze kadar uygulanmaya devam etmiş; hukuki el atmaya ilişkin hükümler ise 6745 sayılı Kanunu'nun yürürlüğe girdiği 07.09.2016 tarihine kadar uygulanmıştır.

\subsection{Sayılı Yatııımların Proje Bazında Desteklenmesi ile Bazı Kanun ve Kanun Hükmünde Kararnamelerde Değişiklik Yapılmasına Dair Kanun Dönemi}

Anayasa Mahkemesi'nin 13.11.2014 tarihli ve E: 2013/95, K: 2014/176 say1lı iptal kararından (URL-9) sonra, kanun koyucu tarafından farklı bir yaklaşım benimsenmiştir. Bu yaklaşım, kamulaştırmasız el atılan taşınmazların fiili ve hukuki olarak ayrıştırılması ve hukuki el atmalar için yeni bir düzenleme yapılmasıdır. Bu kapsamda, 20.08.2016 tarihli ve 6745 sayılı Yatırımların Proje Bazında Desteklenmesi ile Bazı Kanun ve Kanun Hükmünde Kararnamelerde Değişiklik Yapılmasına Dair Kanun ile 04.11.1983 tarihli ve 2942 sayılı Kamulaştırma Kanunu’nda düzenleme yapılmıştır. Yapılan düzenlemeyle 09.10.1956 tarihinden sonra idareler tarafından kamulaştırmasız el atılan taşınmazlardan, hukuki el atma kapsamına girenler için yeni hükümler öngörülmüştür. Bu kapsamda, 6745 sayılı Kanun’un 33'üncü maddesiyle 2942 sayıl1 Kanun'a ek 1'inci madde eklenmiştir. Bu düzenleme öncesinde hukuki el atma kavramı, ilk defa YHGK'nin 15.12.2010 tarihli kararıyla (URL5) tanınmış ve 6487 sayılı Kanun ile 2942 sayılı Kanun'a eklenen geçici 6'ncı maddenin 10'uncu fikrasının 3'üncü cümlesiyle ilk defa mevzuatta yer almıştır. Mevzuatta yer alan bu hükümler, ayrı bir madde olarak yeniden düzenlenmiş; 6745 sayılı Kanun'un 33'üncü maddesi ile de 2942 sayılı Kanun'a ek 1'inci madde olarak eklenmiştir. İki düzenleme arasında, kapsadıkları hukuki el atılan taşınmazlar bakımından farklılıklar bulunmaktadır. 6487 sayılı Kanun'da, 6745 sayılı Kanun'dan farklı olarak uygulama imar planı haricindeki planlarla ve ilgili kanunların (Kültür ve Tabiat Varlıklarını Koruma Kanunu, Boğaziçi Kanunu, vb.) uygulamasıyla tasarrufu kısıtlanan taşınmazlar için de hükümler bulunmaktaydı. Bu kapsamda, konumu itibariyle kısıtlılık içeren, özel kurallara ve kanunlara sahip alanlarda yer alan taşınmazlar, ek 1'inci madde kapsamında değildir. Ek 1'inci maddenin kapsamı, yalnızca uygulama imar planlarında umumi hizmetlere ve resmî kurumlara ayrılmak suretiyle tasarrufu hukuken kısıtlanan taşınmazlardır. Ek 1'inci madde haricinde hukuki el atma olarak değerlendirilen taşınmazlarda, YHGK'nin 15.12.2010 tarihli, E: 2010/5-662, K: 2010/651 sayılı kararının (URL-5) uygulanması öngörülmüştür.

6745 sayılı Kanun ile 2942 sayılı Kanun'a eklenen ek 1'inci maddede, uygulama imar planlarında umumi hizmetlere ve resmî kurumlara ayrılmak suretiyle hukuki el atılan taşınmazlar için çözüm seçenekleri sunulmuştur. Bu kapsamda, bu taşınmazlar 
için imar planının yürürlüğe girmesinden itibaren beş yıllık süre içerisinde imar programlarının veya imar uygulamalarının yapılması, bütçe imkânları dâhilinde ilgili idarelerce kamulaştırılması veya hukuki el atma olarak değerlendirilmesine sebep olan kısıtlılığı kaldıracak şekilde imar planı değişikliği yapılması düzenlenmiştir. Ek 1'inci madde ile ayrı bir düzenleme yapılması sebebiyle 2942 sayılı Kanun'un geçici 6'ncı maddesindeki hukuki el atmaya ilişkin hükümler, 6745 sayılı Kanun'un 34'üncü maddesiyle kaldırılmış ve aynı Kanun'a geçici 11'inci madde eklenmiştir. Eklenen geçici 11'inci maddede, ek 1'inci maddede öngörülen beş yıllık sürenin düzenlemenin yürürlüğe giriş tarihinden itibaren uygulanması düzenlenmiştir. Böylelikle, ek 1'inci madde kapsamında olan ve imar planı ile hukuki el atılan taşınmazların tasarrufunun kısıtlanmaya başladığı tarih dikkate alınmaksızın dava açılabilmesi için 5 yıllık süre ön koşul olarak düzenlenmiştir.

Kanun koyucu tarafından, düzenlemenin gerekçesinde, her ne kadar bu süre içerisinde hukuki el atılan taşınmazların ilgili idarelerce kamulaştırılmaması durumunda, kısıtlılığ kaldıracak plan değişikliği yapılması ile mağduriyetlerin giderilmesinin amaçlandığ belirtilmiş olsa da öngörülen hükmün gerçekleştirilebilmesi mevcut tüze ile çatışmaktadır. Düzenlemenin yürürlüğe girdiği 2016 yılında, plan değişikliği yapılmasının koşulları, 14.06.2014 tarihli ve 29030 Resmî Gazetede yayımlanan Mekânsal Planlar Yapım Yönetmeliği'nde yer almaktadır. Bu Yönetmelik'in 26'ncı maddesinin 3'üncü fıkrasında, sosyal ve teknik altyapı alanlarının kaldırılması, küçültülmesi veya yerinin değiştirilmesine dair plan değişikliklerinin zorunluluk olmadıkça yapılamayacağı belirtilmektedir. Bu kapsamda hukuki el atmalar, "zorunlu plan değişikliği” kapsamında değerlendirilebilir. Ancak fikranın devamında, zorunlu durumlarda değişiklik yapılabilmesi için etki alanı içinde, eş değer yeni bir alanın ayrılması gerektiği belirtilmiştir. Maddede eş değer alan ayrılırken de yüz ölçüm ve konum özelliklerinin korunması, değişikliğin aynı uygulama etabı veya bölge içinde kalması, yaya erişim mesafelerinin dikkate alınması ve yeni tespit edilen alanın değiştirilen fonksiyona özgü tesisin yapılmasına müsait olması şart koşulmuştur. Hukuki el atılan taşınmazlardan, sosyal ve teknik altyapı alanında kalanların kısıtllı̆̆ğının kaldırılabilmesi amacıyla plan değişikliği yapılabilmesi için 6745 sayılı Kanun'da öngörülmeyen yükümlülüklerin Mekânsal Planlar Yapım Yönetmeliği'nde yer alması, idarelerin elinde olan seçenekleri sınırlamaktadır. İdarelerin; eğer kendi taşınmazı mevcut ise söz konusu kısıtlılık alanı için eş değer alan olarak ayırması (trampa), başka bir taşınmazı eş değer alan olarak ayırarak yeni hukuki el atma oluşturması (yerini değiştirme), Yönetmelik'e aykırı şekilde eş değer alan ayırmadan söz konusu alanı plan bütünlüğünü bozacak şekilde tamamen kaldırması, plan değişikliği talebini reddetmesi ve imar planının tamamında değişiklik yaparak donatı alanı dengesini yeniden tesis etmesi gibi seçenekleri bulunmaktadır. Bu seçeneklerin her birinin başka yeni sorunları ortaya çıkaracak olması, hukuki el atılan taşınmazlar için öngörülen plan değişikliği ile kısıtllılı̆ın kaldırılmasının verimli bir çözüm sunamadığını göstermektedir. Bu sorunlarına rağmen, hukuki el atılan taşınmazlar için kısıtlılığı kaldıracak şekilde plan değişikliği yapılması seçeneği, 2020 yılına kadar uygulama olanağı bulmuştur. Ancak 14.02.2020 tarihli ve 7221 sayılı Coğrafi Bilgi Sistemleri ile Bazı Kanunlarda Değişiklik Yapılması Hakkında Kanun ile 3194 sayılı Kanun'a eklenen geçici 8'inci madde ile parsel bazında nüfusu, yapı yoğunluğunu, kat adedini, bina yüksekliğini arttıran imar planı değişiklikleri yapılamayacağı hüküm altına alınmıştır. Bu kapsamda, uygulama imar planlarında umumi hizmetlere ve resmî kurumlara ayrılmak suretiyle hukuki el atılan taşınmazlarda kısıtllığı kaldıracak şekilde imar planı değişikliği yapılması durumunda, parselin nüfus ve yapı yoğunluğu gibi özelliklerinin artacağı kesin olduğundan yasaya aykırılık oluşacaktır. Bu kapsamda 3194 sayılı Kanun'da yapılan değişiklikte, hukuki el atılan taşınmazlar için bir istisna öngörülmemiştir. Bu çalışmanın yayımlandığı tarih itibariyle hem 2942 sayılı Kanun'un ek 1'inci maddesinde yer alan "mülkiyet hakkını kullanmasına engel teşkil edecek kısıtlllığı kaldıracak şekilde imar planı değiş̧ikliği yapılır/yaptırllır" hükmü, hem de 3194 sayılı İmar Kanunu'nun geçici 8'inci maddesinde yer alan "parsel bazında; nüfusu, yapı yoğunluğunu, kat adedini, bina yüksekliğini arttıran imar planı değişiklikleri yapılamaz" hükmü birbirleriyle çatışmasına rağmen halen yürürlüktedir.

6745 sayılı Kanun ile 2942 sayılı Kanun'a eklenen ek 1'inci maddede öngörülen işlemlerin idarelerce 5 yıl içerisinde gerçekleştirilememesi halinde ise geçici 6'ncı maddede düzenlenen uzlaşma sürecinin ve 3194 sayılı İmar Kanunu'nda 
öngörülen idari başvuru süreçlerinin tamamlanması şartıyla idari yargıda dava açılabileceği hükme bağlanmıştır. Ancak düzenlemede, “Imar Kanunu’nda öngörülen idari başvuru ve işlemleri” hükmünün içeriği tam olarak belirtilmemiştir. Düzenlemenin atıf yaptığı 3194 sayılı Kanun irdelendiğinde, bu kapsamda yalnızca 13'üncü maddede yer alan ancak Anayasa Mahkemesi'nin 29.12.1999 tarihli ve E: 1999/33, K: 1999/51 sayılı kararı (URL-10) ile iptal edilen "parsel sahibi imar planlarının tasdik tarihinden itibaren beş yıl sonra müracaat ettiğinde imar planlarında meydana gelen değişikliklerden ve civarın özelliklerinden dolayı okul, cami ve otopark sahası ve benzeri umumî hizmetlere ayrlan alanlardan ilgili kamu kuruluşunca yapımından vazgeçildiğine dair görüş alındiğı takdirde, tüm belirli çevredeki nüfus, yoğunluk ve donatım dengesini yeniden irdeleyerek hazırlanacak yeni imar plânına göre inşaat yapılır." hükmü anlamlıdır. Ancak maddenin düzenlendiği tarih itibariyle ilgili hükümlerin uygulanma olanağı olmadığından, 3194 sayılı Kanun'da bu kapsamda yalnızca imar programlarının kamulaştırma ve kısıtlılık halinin düzenlendiği 10'uncu madde mevcuttur. Bu madde içeriğinde, ek 1'nci maddede öngörülen işlemlerden farklı bir uygulama tanımlanmadığından, dava şartı olarak maliklerin eylemsiz kalan idareye, eylemsiz kalması sebebiyle aynı eylemleri talep etmeleri düzenlenmiştir.

Maliklerin dava şartı olarak öngörülen bu işlemleri tamamlamaları durumunda açılan davalarda, hukuki el atılan taşınmazların değerinin bilirkişi incelemesi yapılarak kısıtlılığın veya fiilen el atmanın gerçekleştiği tarihteki niteliklerinin esas alınması düzenlenmiştir. Ayrıca yapılan düzenlemede idare mahkemeleri, tescil ve terkin işlemlerinde yetkili hale getirilmiş ve bedel tespit davalarında hukuki el atılan taşınmazların idare adına tescil edilebilmesi sağlanmıştır. Düzenleme, yalnızca hukuki el atılan taşınmazları kapsamasına rağmen değerleme tarihi olarak "fiilen el koymanın gerçekleştiği tarih" öngörülmüştür. Bu karışıklık, Yalçınduran (2017) tarafından Kanun’un taslak metinlerinde, fiilen el koyulan taşınmazlara ait düzenlemelerin de yer alması ancak komisyon çalışmaları sırasında, fiili el atmaların metinden çıkarılmasına rağmen söz konusu ifadenin sehven unutularak kaldırılmamış olması ile açıklanmaktadır.

Maddenin geçerli olduğu hukuki el atmalara dair açılan ve açılacak davalarda farklı hükümler geçerlidir. Maddenin yürürlüğe girdiği tarihten önce açılan ancak henüz karara bağlanmayan veya kararı kesinleşmeyen davalarda, ek 1'inci madde hükümlerinin uygulanması düzenlenmiştir. Açılacak davalarda ise geçici 6'ncı maddenin uzlaşma şartlarını düzenleyen 3'üncü fikrasının, harç ve ücretlerin hesabında kullanılacak yöntemi belirleyen 7'nci fikrasının, ödemelerde kullanılacak yöntemlerin ve özellikle de taksitli ödeme yönteminin detaylarını içeren 8'inci fıkrasının ve ödemelerin tahsilinde idarelerin mal ve alacaklarının haczedilemeyeceğini düzenleyen 11'nci fikrasının uygulanacağı düzenlenmiştir. Buna ek olarak kesinleşen ancak henüz ödemesi yapılmayan kararlar hakkında ise geçici 6'ncı maddenin 3'üncü (uzlaşma koşulları), 8'inci (taksitlendirme) ve 11'inci (idarenin haczedilemeyeceği) fikra hükümlerinin uygulanacağı hüküm altına alınmıştır. Buna ek olarak geçici 6'ncı maddenin 8'inci fikrası uyarınca ayrılması düzenlenen \%2 oranındaki ödeneklerin \%4'e çıkarılması ve yeni ayrılan miktarın geçici 11 ve geçici 12 maddeleri kapsamındaki ödemelerde kullanılması düzenlenmiştir. Bu kapsamda yapılacak ödemelerin toplam tutarının ödenek miktarını aşması durumunda ise 8'inci fikra hükümlerine göre en çok 10 yıl taksitlendirilerek ödenmesi hüküm altına alınmıştır.

6745 sayılı Kanun'un 34'üncü maddesiyle yapılan düzenleme, devam eden davaları malikler bakımından olumsuz etkilemiştir. İdari mahkemelerce devam eden davalarda, yürürlüğe giren kanun maddesinde öngörülen sürenin dava konusu taşınmazlar için dolmadığı gerekçe gösterilerek dava hakkında karar verilmesine yer olmadığı şeklinde kararlar alınmıştır. Buna bağlı olarak da maliklerce Anayasa Mahkemesi'ne bireysel başvurular yapılmıştır (URL-11: Anayasa Mahkemesi Hüseyin Ünal başvurusu, T: 20.09.2018 ve Başvuru No: 2017/24715; URL-12: Anayasa Mahkemesi Bülent Eren ve Diğerleri Başvurusu, T: 31.10.2018, Başvuru No: 2017/27308). Malikler tarafından yapılan başvurulara ek olarak, Ankara 2. İdare Mahkemesinin 2016/196 Esas sayılı (URL-13) ve Adana 3. İdare Mahkemesinin 2017/41 Esas sayıl1 kararlarıyla (URL-14) geçici 11'inci maddenin Anayasa'nın 152'nci maddesi uyarınca incelenmesi talep edilerek Anayasa Mahkemesi'ne 
gönderilmiştir. Yapılan incelemenin sonucunda, 20.8.2016 tarihli ve 6745 sayılı Kanun'un 34'üncü maddesiyle 04.11.1983 tarihli ve 2942 sayılı Kamulaştırma Kanunu'na eklenen geçici 11'inci maddenin birinci ve ikinci fikraları, kamu yararı ile malikin mülkiyet hakkı arasında gözetilmesi gereken adil dengeyi malik aleyhine bozması ve malike aşırı bir külfet yüklemesi sebebiyle Anayasa Mahkemesi'nin 28.03.2018 tarihli ve E: 2016/196 ve K: 2018/34 sayılı kararıyla (URL-15) iptal edilmiştir. Bu kararla her taşınmaz için 2942 sayılı Kanun’un ek 1'inci maddesinde öngörülen 5 yıllık sürenin ilgili imar planının yürürlüğe girdiği tarih esas alınarak hesaplanması hükme bağlanmıştır. Anayasa Mahkemesi’nin almış olduğu iptal kararı resmi gazetede yayımlandığı gün yürürlüğe girmiştir.

Bu karardan kısa bir süre sonra da Anayasa Mahkemesi’nin 20.12.2018 tarihli ve E: 2016/181, K: 2018/111 sayıl1 kararı (URL-16) ile 6745 sayılı Kanun'un 33'üncü maddesi ile 2942 sayılı Kanun'a eklenen ek 1'inci maddenin ilk cümlesi haricindeki tüm madde içeriği iptal edilmiştir. İptal kararıyla (URL-16) imar planı ile taşınmazlarına hukuki el atılan malikler tarafından uzlaşma ya da idari başvuru ve işlem süreçleri tamamlamadan dava açılabilmesi hüküm altına alınmıştır. Kararın gerekçesinde, mülkiyet hakkını kısıtlayan imar planı değişikliğinin yapılmaması hâlinde, taşınmazın ilgili idare tarafından öngörülen kamulaştırma işleminin Anayasa'da öngörülen ilkelere göre yapılması gerektiği belirtilmiştir. Kararda, 6745 sayılı düzenlemenin öngördüğünden farklı olarak taşınmazların gerçek karşılıklarının nakden ve peşin olarak ödenmesi, istisnai hâllerde ise taksitlendirme süresinin beş yılı aşamaması, taksitlendirmelerde ve ödenmemiş kamulaştırma bedellerinde kamu alacakları için öngörülen en yüksek faizin uygulanması gerektiği belirtilmiştir. Ayrıca daha önce Anayasa Mahkemesi tarafından verilen 01.11.2012 tarihli ve E:2010/83, K:2012/169 sayılı iptal kararında (URL-8) belirtilen gerekçelere atıfta bulunulmuştur.

Böylelikle, 09.10.1956 ile 04.11.1983 tarihleri arasında gerçekleşen mağduriyetlerin giderilmesi amacıyla çıkarılan ve istisnai nitelik taşıyan hükümlerin geleceğe yönelik olarak uygulanmasını amaçlayan 25.02.2011 tarihli ve 6111 sayılı Kanun ile düzenlenen hükümler, 01.11.2012 tarihli ve E:2010/83, K:2012/169 sayılı Anayasa Mahkemesi kararıyla (URL-8); 11.06.2013 tarihli ve 6487 sayılı Kanun ile düzenlenen hükümler, 13.11.2014 tarihli ve E: 2013/95, K: 2014/176 say1l Anayasa Mahkemesi kararıyla (URL-9); son olarak da 20.08.2016 tarihli ve 6745 sayılı Kanun ile düzenlenen hükümler, 20.12.2018 tarihli ve E: 2016/181, K: 2018/111 sayılı Anayasa Mahkemesi kararlarıyla (URL-16) iptal edilmiştir. Kanun koyucunun kamulaştırmasız el atma davalarında istisnai hükümlerin geçerli olduğu 09.10.1956 ile 04.11.1983 dönemini genişleterek bu hükümlere tabi olacak taşınmazların arttırılmasını amaçlayan girişimleri, farklı kanunlarla düzenlenmesine rağmen gerçekleştirilememiştir.

Bu dönem içerisinde değişen hükümlerin tamamı, hukuki el atmaları düzenlemektedir. Fiili el atmalara ilişkin bir değişiklik yaşanmamış ve 13.09.2015 - 20.08.2016 tarihleri arasında geçerli hükümler (Tablo 7) 2020 yılı itibariyle halen yürürlüktedir. Hukuki el atılan taşınmazlara ilişkin farklı hükümlerin geçerli olduğu zaman aralıkları ile bu zaman aralıklarında hukuki el atmanın niteliğine ve tarihine bağlı olarak maliklere tanınan dava hakları ve ilgili koşullar Tablo 8'de verilmiştir.

Tablo 8'de özetlenen bu dönem içerisinde, 6745 sayılı Kanun ile yalnızca Uygulama İmar Planı ile hukuki el atılan taşınmazlara ilişkin hükümler düzenlenmiştir. Diğer hukuki el atmalarda ise YHGK'nin 15.12.2010 tarihli ve E: 2010/5-662, K: 2010/651 sayılı kararı uyarınca tazminat ve bedel davası açılabilmesi yürürlükte kalmıştır. Bu dönemde, taşınmazlarına Uygulama İmar Planı ile hukuki el atılan maliklere tanınan hakları düzenleyen, farklı hükümlerin geçerli olduğu üç zaman aralığı öne çıkmaktadır. Bunlardan ilki, 6745 sayılı Kanun’un yürürlüğe girdiği 07.09.2016 tarihi ile başlayıp Anayasa Mahkemesi’nin E: 2016/196 ve K: 2018/34 sayılı kararının yürürlüğe girdiği 28.03.2018 tarihiyle sonlanmıştır. Bu tarihler arasında maliklerin dava açmaları sırasıyla; kısıtlılığın başladığı tarihe bağlı olmaksızın 5 yıllık süre, uzlaşma ve idari başvuru ve işlemlerin tamamlanması ön koşullarına bağlanmıştır. Bu hükümler uyarınca, maliklerin dava açabilmesi için 
taşınmazlarının imar uygulamasıyla edinilmesini, kamulaştırılmasını ya da kısıtlılığı kaldıracak imar planı değişikliği yapılmasını beklemesi düzenlenmiştir. Bunların gerçekleşmemesi durumunda ise uzlaşmaya başvurarak uzlaşma sürecini beklemesi ve uzlaşmanın sağlanamaması durumunda dava açabilmesi gibi uzun bir yol tasarlanmıştır. Bu yolu tüketen maliklerin açtıkları davalarda ise yapılacak ödemelerin taksitlendirilerek on yıla kadar yayılabilmesi ve idarelerce ödemelerin yapılmaması durumunda maliklerin haciz yoluna başvuramaması öngörülmüştür. Bu zaman aralığı içerisinde devam eden ve yeni açılan birçok davada, mahkemelerce maliklerin bu yolu tüketmedikleri belirtilerek davalarda karar vermeye yer olmadığına ya da davaların reddine karar verilmiştir. Bu hükümlerden 5 yıllık sürenin Kanun'un yürürlüğe girmesi ile başlaması, Anayasa Mahkemesi’nin 28.03.2018 tarihli ve E: 2016/196 ve K: 2018/34 sayılı kararıyla iptal edilerek, 5 y1llık sürenin kısıtlılığa sebep olan ilgili imar planının yürürlüğe girmesinden itibaren başlaması hüküm altına alınmıştır. Bu karar, bu dönem içerisinde hukuki el atmalara ilişkin farklı hükümlerin geçerli olduğu ikinci zaman aralığının başlangıcını oluşturmuştur. Bu karardan sonra geçici 6’ncı maddenin, maliklerin haklarını kısıtlayan hükümlerinin hukuki el atmalar için geçerli olması, Anayasa Mahkemesi'nin 20.12.2018 tarihli ve E: 2016/181, K: 2018/111 sayılı kararı ile iptal edilerek, imar planı ile taşınmazlarına hukuki el atılan malikler tarafından uzlaşma ya da idari başvuru ve işlem süreçleri tamamlanmadan dava açılabilmesi sağlanmıştır. Bu dönem, farklı hükümlerin geçerli olduğu son zaman aralığını oluşturmuştur.

Tablo 8: Kamulaştırmasız el atmaya ilişkin farklı tarihlerde geçerli hükümler

\begin{tabular}{|c|c|c|c|c|}
\hline \multicolumn{5}{|c|}{ nlerin Geçerli Oldugu Done } \\
\hline & nan Aralığı: & $\begin{array}{c}07.09 .2016^{(1)}-28.03 .2018^{(2)} \\
\text { Arası } \\
\end{array}$ & $\begin{array}{c}\text { 28.03.2018 }-20.12 .2018^{(3)} \\
\text { Arası } \\
\end{array}$ & $\begin{array}{l}20.12 .2018 \\
\text { Sonrası }\end{array}$ \\
\hline & & Tüm El & & \\
\hline $\begin{array}{r}\text { Uyg } \\
\text { İmar } \\
\text { Hul } \\
\text { At }\end{array}$ & $\begin{array}{l}\text { t } \\
\text { ası }\end{array}$ & $\begin{array}{c}\text { Açılabilir } \\
\text { Ön koşul: 07.09.2016 } \\
\text { tarihinden itibaren } \\
5 \text { yıllık süre }{ }^{(5)}, \text { uzlaşma }^{(6)} \text { ve } \\
\text { idari işlemler }^{(7)} \\
\text { El atma tar. nitelikleri } \\
\end{array}$ & $\begin{array}{r}\text { Ön koşul: } \\
\text { yürürlük t: } \\
5 \text { yıllık sür } \\
\text { idari } \\
\text { El atma }\end{array}$ & $\begin{array}{c}\text { Açılabilir } \\
\text { Ön koşul: } \\
5 \text { yıllık süre } \\
\text { Dava tar. } \\
\text { nitelikleri }\end{array}$ \\
\hline El Atmalar & & & Açılabilir & \\
\hline \multicolumn{5}{|c|}{ 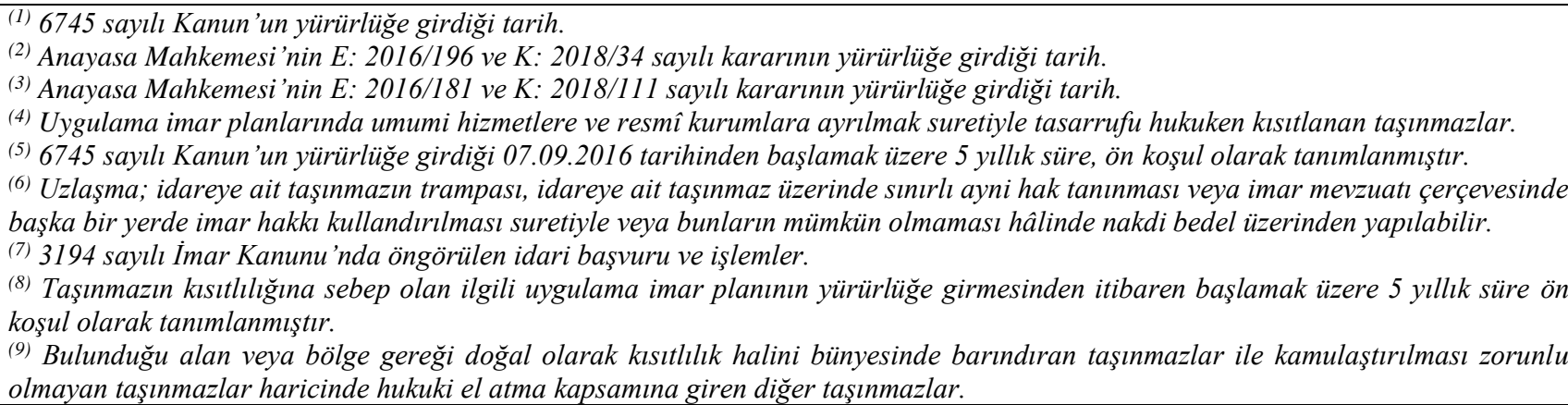 } \\
\hline
\end{tabular}

Kanun koyucu tarafından maliklerin dava haklarını 5 yıl öteleyen hükümlerin, devam eden davalara da uygulanması ile tüm davaların sonlandırılması amaçlanmıştır. Böylelikle 5 yıl boyunca hukuki el atma davası açılamaması, bu sürenin sonunda ise tüm davaların yeni getirilen kısıtlayıcı hükümlere tabi olması tasarlanmıştır. Bu bağlamda, İdare Mahkemelerinde kamulaştırmasız el atmadan doğan işler kapsamına giren davalarda, "karar verilmesine yer olmadığına" karar verilen dava sayısı 2015 yılında 3 (URL-17) iken ilgili hükmün yürürlüğe girmesiyle bu yönde alınan kararlarda büyük bir artış yaşanmıştır. Hükümlerin yürürlükte olduğu 2016 yılında 2388 davada (URL-18) ve 2017 yılında 659 davada (URL-19) “karar verilmesine yer olmadığı” kararı verilmiştir. Benzer şekilde bu hüküm öncesinde, 2015 yılında (URL-17) kamulaştırmasız el atmadan doğan işler kapsamına giren davalarda "ret" kararı verilen dava sayısı 34 iken hükmün yürürlüğe girmesiyle reddedilen dava sayısında da büyük bir artış yaşanmıştır. Hükümlerin yürürlükte olduğu 2016 yılında 783 dava (URL-18) ve 2017 yılında 345 dava (URL-19) reddedilmiştir. Ancak kanun koyucunun bu yaklaşımı, Anayasa Mahkemesi’nin ilgili 
hükmü iptal etmesi ile yarıda kalarak 2018 yılında (URL-20) "karar verilmesine yer olmadığına" karar verilen dava sayısı 30'a; ret kararı verilen dava sayısı ise 130'a düşmüştür. Bu süreç hem mahkemelerin iş yükünün artmasına hem de maliklerin mağdur olmasına sebep olmuştur. Bu süreçte Anayasa Mahkemesi'nin iptal kararının, kararın alındığı gün yürürlüğe girmesi mağduriyetlerin artmasını engellemiştir.

Bu dönem içerisinde ayrıca kanun koyucu tarafından kamulaştırma bedellerinin ödenmesine yönelik iki önemli değişiklik yapılmıştır. Bunlardan ilki, 30.05.2019 tarihli ve 7176 sayılı Bazı Kanunlar ile 635 sayılı Kanun Hükmünde Kararnamede Değişiklik Yapılmasına Dair Kanun'un 21'inci maddesi ile 2942 sayılı Kamulaştırma Kanunu'na geçici 14'üncü maddenin eklenmesidir. Geçici 14'üncü madde ile kamulaştırmasız el atma davalarında, idarenin mallarının haczedilememesine yönelik iptal edilen hükümler değiştirilerek yeniden düzenlenmiştir. Madde içeriğinde, 04.11.1983 tarihinden düzenlemenin yürürlüğe girdiği tarihe kadar, kamulaştırmasız el atılan taşınmazlara dair bedele ve tazminata ilişkin davalarda verilen mahkeme kararları kesinleşmedikçe icraya konulamayacağı düzenlenmiştir. Yapılan düzenlemeyle maliklere yapılacak kamulaştırma bedeli ödemelerinin geciktirilmesi amaçlansa da düzenlemenin iptali için Anayasa Mahkemesi'ne başvuru yapılması halinde, geçici 14'üncü maddenin de iptal edilebileceği düşünülmektedir. Yapılan ikinci değişiklik ise 24.12.2019 tarihli ve 7201 sayılı Kamulaştırma Kanunu ile Bazı Kanunlarda Değişiklik Yapılmasına Dair Kanun'un 5'inci, 6'ncı ve 7'nci maddesi ile 2942 sayılı Kamulaştırma Kanunu'na ek madde 2, ek madde 3 ve geçici 15'inci maddenin eklenmesidir. Düzenlenen ek madde 2 ile 08.12.2004 tarihinde kaldırılan Arsa Ofisi Genel Müdürlüğüne karşı açılan davalardan, bu tarihten önce açılanların Çevre ve Şehircilik Bakanlığına; bu tarihten sonrakilerin ise ilgili kurumun görevlerini devralan Toplu Konut İdaresi Başkanlığına yöneltilmesi düzenlenmiştir. Ek madde 3 ile de daha önce 6487 sayılı Kanun’un 22'nci maddesiyle 2942 sayılı Kanun'a eklenen ancak 13.11.2014 tarihinde Anayasa Mahkemesi'nin E: 2013/95, K: 2014/176 say1l kararı (URL-9) ile iptal edilen geçici 7'nci maddenin kapsamındaki taşınmazlara ilişkin yeni hükümler getirilmiştir. Bu kapsamda, ek madde 3'ün kapsamı artık yürürlükte olmayan 6830 sayılı ve 2942 sayılı Kanun'ların 16 ve 17'inci maddeleri uyarınca mahkemelerce idare adına hükmen tescil kararı verilen kamulaştırmalar olmuştur. Madde ile taşınmazların idare adına tescil edildiği tarihteki niteliklerinin esas alınması ile bulunacak bedelin, Türkiye İstatistik Kurumu tarafından açıklanan Yurt İçi Üretici Fiyat Endeksi (Yİ-ÜFE) tablosundaki aylık değişim oranları kullanılarak dava tarihine güncellenmesi ve maliklere ödenmesi hüküm altına alınmıştır. Geçici madde 15 ile de ek 2'nci ve ek 3'üncü maddelerle getirilen hükümlerin, Kanun'un yayımlanmasından önce açılmış ve devam eden davalar ile icra takipleri hakkında da uygulanması düzenlenmiştir. Bu düzenleme kapsamındaki taşınmazların kamulaştııılmış sayılarak dava haklarının engellenmesine yönelik hükümlerin iptal edilmesi sonucunda kanun koyucu tarafından bu sefer ödenecek bedellerin düşürülmesine yönelik düzenlemeler getirilmiştir.

Bu dönem içerisinde fiili el atmalara ilişkin kapsamlı bir düzenleme yapılmamış ve Anayasa Mahkemesi'nin 13.11.2014 tarihli ve E: 2013/95, K: 2014/176 sayılı kararı ile şekillenen hükümler, günümüze kadar uygulanmaya devam etmiştir. Hukuki el atmalara ilişkin ise 6745 sayılı Kanun yapılan düzenlemeler, Anayasa Mahkemesi’nin E: 2016/196, K: 2018/34 sayllı ve E: 2016/181, K: 2018/111 sayılı kararları ile son halini alarak halen yürürlükte olan hükümler oluşmuştur. Bir sonraki dönemde, kanun koyucu tarafından hukuki el atma kavramının oluşmasına sebep olan kısıtlllığın kaldırılmasına yönelik hükümler düzenlenmiştir.

\subsection{Sürecin Son Unsuru: 7181 Sayılı Tapu Kanunu ve Bazı Kanunlarda Değişiklik Yapılmasına Dair Kanun'un ve Arazi ve Arsa Düzenlemeleri Hakkında Yönetmelik Dönemi}

Anayasa Mahkemesi'nin 20.12.2018 tarihli ve E: 2016/181, K: 2018/111 sayılı kararı (URL-16) ile 6745 sayıl1 Kanunla düzenlenen birçok hükmün iptal etmesinden sonra, 22.02.2020 tarihli ve 31047 sayılı Resmi Gazetede yayımlanan Arazi ve Arsa Düzenlemeleri Hakkında Yönetmelik ile hukuki el atılan taşınmazlara ilişkin düzenlemeler yapılmıştır. Bu düzenlemeler, 04.07.2019 tarihli ve 7181 sayılı Tapu Kanunu ve Bazı Kanunlarda Değişiklik Yapılmasına Dair Kanun'un 
7'nci maddesi ile değiştirilen 3194 sayılı İmar Kanunu'nun 13'üncü maddesine dayanmaktadır. Yapılan bu değişiklik, hukuki el atılan taşınmazlara ilişkin kısmen sorunun çözümüne odaklanan bir düzenlemedir. Kanun koyucu tarafından maddenin gerekçesinde, uygulama imar planlarında umumi hizmet alanına ayrılan veya kamulaştırılması gereken alanların kamu eline geçmesinin sağlanmasının ve kamulaştırma yükü ile kamulaştırmasız el atmadan kaynaklanan sorunların azaltılmasının amaçlandığı belirtilmiştir. Maddenin 2'nci fıkrasında, düzenleme ortaklık payına konu kullanımlardan yol, meydan, ibadet yerleri, park ve çocuk bahçeleri hariç olmak üzere yapı yapılabilecek diğer alanlarda, alanların kamuya geçişi sağlanıncaya kadar plandaki kullanım amacına uygun özel tesis yapılabilmesi hüküm altına alınmıştır. Ancak bu durum, maliklerinin talebine ve ilgili kamu kuruluşunun uygun görüşüne bağlanmıştır. Bu fikranın uygulanmasına ilişkin usul ve esaslar ise Yönetmelik'in 6'ncı maddesinde verilmiştir. Bu maddelere göre, düzenleme ortaklık payına konu kullanımlardan yol, meydan, ibadet yerleri, park ve çocuk bahçeleri hariç olmak üzere yapı yapılabilecek diğer alanlarda, madde içeriğinde verilen kurallara bağlı olarak, plandaki kullanım amacına uygun özel tesis yapılabilmesi düzenlenmiştir. Böylelikle, taşınmazlarına hukuki el atılan maliklerden bazılarının belirli kısıtlamalar dâhilinde de olsa imar hakkını kullanabilmesi sağlanmış ve piyasada işlem görebilmesi kolaylaşmıştır.

Aslında bu yaklaşım, düzenlemeden önce de belediyeler tarafından hukuki el atma davalarının sonuçlarından kaçmak üzere kullanılmaktaydı. Bu bağlamda, belediyelerce hukuki el atılan taşınmazların kamusal fonksiyonlarının, özel fonksiyona dönüştürülmesi gerçekleştirilmekteydi. Örneğin; Ankara Büyükşehir Belediye Meclisinin 14.01.2013 tarihli ve 150 no’lu kararında (URL-21), "Spor Alanı” fonksiyonunda kalan parselin maliklerince idare aleyhine açılan kamulaştırmasız el atma davasında, kararın idare aleyhine olması sebebiyle taşınmazın plan amacına uygun kullanılabilmesi amacıyla "Özel Spor Alanı” fonksiyonuna dönüştürülmesi kararlaştırılmıştır.

Düzenlemede, imar planı ile kısıtlanan taşınmazlarda yapılacak ilgili fonksiyona özgü özel tesisin kamuya geçişi sağlanıncaya kadar kullanılması belirtilmiştir. Ayrıca bu işlemin yapılabilmesi için de hem söz konusu fonksiyon sınırları içerisinde yer alan tüm maliklerin talebinin hem de ilgili idarenin onayının olması hüküm altına alınmıştır. Bu koşulların sağlanması durumunda ise ilgili özel tesisin izin verilen hali ile kalmasını sağlayacak kurallar, maddenin 2'nci fikrasında düzenlenmiştir. Bu kapsamda, taşınmazın tapu kütüğünün beyanlar hanesine, ilgili idare tarafından imar planındaki kullanım fonksiyonu ve süresi ile imar planındaki kullanım amacı dışında kullanılamayacağı, hiçbir şekilde imar plan değişikliği ile özel mülkiyete konu fonksiyon getirilemeyeceği, umumi ve kamu hizmet fonksiyonu dışında kullanılamayacağına dair belirtme yapılması düzenlenmiştir. Maddenin 3'üncü fıkrasında, söz konusu tesisin izin, projelendirme ve inşaat aşamalarını da içeren tüm proje ve yapım işlemlerinde, tesisten yükümlü idare ile bağlı olduğu idarenin kontrol ve takibinde gerçekleşmesi düzenlenmiştir. Maddenin 4'üncü fikrasında ise ilgili tesisin maliklerince kullanımına ve kamuya geçişine ilişkin hükümler düzenlenmiştir. Bu kapsamda malik tarafından yapılacak tesisin 10 yıl malik tarafından kullanılması ve idarenin onayına bağlı olarak kullanımın 5'er yıllık süreler halinde yenilenebileceği düzenlenmiştir. İdarenin ilgili taşınmazı kamulaştırmaya karar vermesi durumunda, izin verilen sürenin bitimine bir yıl kala malike bildirme zorunluluğu düzenlenmiştir. Kullanım süresinin bitmesinden sonra, kamu hizmetini sağlamakla yükümlü idare tarafından parsel ve üzerinde izin verilen yapının Kamulaştırma Kanunu'na göre kamulaştırılarak kamuya geçişinin sağlanacağı belirtilmiştir. Yapılan bu düzenleme özü itibariyle 6785 sayılı Kanun'da yer alan, maliklerin idareye başvurmalarından itibaren beş yıl içerisinde kamulaştırılmadığı takdirde inşaat haklarını kullanmalarına geçici olarak izin veren hükme benzemektedir. Her iki düzenlemede de kanun koyucu tarafından benimsenen yaklaşım; maliklerin inşaat yapabilme kısıtlılı̆̆ının ortadan kaldırılması durumunda, el atmanın da ortadan kalkacağıdır. Bu bağlamda düzenleme, donatı alanlarında özel tesis yapılması ile planlama kapsamında tartışmalı olsa da bu kapsamdaki taşınmazlarda el atma olgusunu ortadan kaldıracaktır. Bu durum, devam eden ve açılacak birçok hukuki el atma davalarını doğrudan engelleyecektir. Çünkü hukuki el atmanın varlığı, mülkiyet hakkının kısıtlanmış olmasına bağlıdır. Bu kapsamda, taşınmazların imar planıyla hizmet alanlarına ayrılmış ve 
taşınmaz üzerinde yapılaşmanın kısıtlanmış olması gerekmektedir. Taşınmazların imar planıyla hizmet alanına ayrılmasına rağmen malik tarafından özel kullanımının ve yapı yapılabilmesinin mümkün olması durumunda, hukuki el atma ortadan kalkmış olacaktır. Bu kapsamda, Danıştay Altıncı Dairesinin 18.10.2016 tarihli, E: 2016/199, K: $2016 / 5740$ sayılı ve 27.09.2016 tarihli, E: 2015/9786 K: 2016/4868 sayılı kararları (aktaran: Yavuz, 2018, s. 104) örnek teşkil etmektedir. Bu kararlarda, plan değişikliği yapılarak imar planında spor alanı olan taşınmazın, "özel spor alanı" ve sosyal kültürel tesis alanı olarak belirlenen taşınmazın, "özel sosyal kültürel tesis alanı" olarak değiştirilmesiyle mülkiyet hakkının hukuka aykırı bir şekilde kısıtlandığından bahsedilemeyeceğine ve hukuki el atma nedeniyle ödenmesi gereken bir tazminatın bulunmadığına karar verilmiştir. Danıştay Altıncı Daire tarafından verilen bu kararlarda, dava konusu taşınmazlar için sadece kamu eliyle yapılaşması zorunluluğunun ortadan kalktığı ve malikler tarafından yapılaşma hakkının kullanılabileceği belirtilmiştir. Ayrıca bu kararlarda, özel mülkiyete konu olacak şekilde kullanım amacının değiştirilmesiyle ortada imar planından kaynaklanan nedenlerle kamulaştırılması gereken bir taşınmaz ya da ödenmesi gereken bir tazminatın kalmamasıyla mülkiyet hakkının hukuka aykırı bir şekilde kısıtlandığından bahsedilemeyeceği belirtilmiştir. Bu kararlardan yola çıkıldığında, 3194 sayılı Kanun'da yapılan düzenleme ile Kanun'da belirtilen alanlarda, plandaki kullanım amacına uygun özel tesis yapılabilmesinin sağlanması, hukuki el atma davalarının sayısını azaltacaktır. Düzenleme, kısa vadede hukuki el atma olarak değerlendirilen ve değerlendirilecek taşınmazları ve ödenmesi gereken tazminat ve kamulaştırma bedellerini azaltacaktır. Ancak uzun yıllar boyunca maddi imkânsızlıklar sebebiyle yalnızca parselin kamulaştırmasını gerçekleştiremeyen idarelerin aradan geçecek en az 10 yıllık sürenin sonunda, parsele ek olarak yapının değerinin de eklenmesiyle oluşacak yüksek kamulaştırma bedelini karşılayamayacağı düşünülmektedir. $\mathrm{Bu}$ işleme talebin çok olması durumunda ise gelecekte yeni istisnai hükümlerin, bu sefer 3194 kapsamında gerçekleştirilmesi ya da kamusal hizmetlerin kamu yerine özel sektör tarafından üretilmesi ve işletilmesi olasıdır.

$\mathrm{Bu}$ düzenlemenin arsa ve arazi düzenlemesi uygulamalarında, düzenleme ortaklık payının Kanun'da öngörülenden fazla çıkması durumunda, idareler tarafından gerçekleştirilmesi gereken kamulaştırma işlemlerinde de uygulanması olasıdır. Kanun koyucu tarafından, düzenleme sahasındaki umumi ve kamu hizmet alanlarının yüzde kırk beşi (\%45) aşması durumunda, parsellerin kamu ve umumi hizmet alanlarına denk gelen kısımlarının özel mülkiyet adına tescil edilmesi hüküm altına alınmıştır. Bu parsellere, hizmeti vermekle sorumlu kurumca kamulaştırılacağı şerhi düşülecektir. Bu kapsamda, taşınmazlardan hangilerinin bedelsiz DOPO kesintisiyle, hangilerinin ise kamulaştırma ile karşılanacağı Yönetmelik’in 14'üncü maddesinde verilen sıralamaya göre belirlenecektir. Siralama incelendiğinde, DOPO ile edinimde, önceliğin yol, su yolu, meydan, park, otopark, çocuk bahçesi/parkı, yeşil alan, ibadet yeri ve karakol gibi özel tesis yapılmasına konu olmayan alanlarda olduğu görülmektedir. Oysa özel tesis yapılmasına konu olabilecek eğitim tesis alanları ile kreş alanları 2'nci sırada, sağlık tesis alanları 4'üncü sırada ve sosyal, kültürel tesis alanları 7'nci sırada tanımlanmıştır. Böylelikle, özel mülkiyete konu olabilecek alanların DOPO dışında kalmaları olasıdır. Yönetmelik’te, kamulaştırılması gereken taşınmazların parselasyon işleminin tescilinden itibaren 5 yıl içerisinde kamu mülkiyetine geçirilmesinin zorunlu olduğu ve bu süre, sorumlu idarenin kararı ile gerekçeleri belirtilerek en fazla 1 yıl uzatılabileceği belirtilmiş olsa da tıpkı imar programlarında olduğu gibi işlemi gerçekleştirmeyen idareler hakkında herhangi bir hüküm bulunmamaktadır. Bu hali ile yeni hukuki el atmaların ve buna bağlı olarak da umumi hizmet alanlarının özel mülkiyete konu olmasının mümkün olduğu düşünülmektedir. Yapılan bu düzenlemenin henüz yürürlüğe girmesi ve 10.07.2019 tarihinden sonra onaylanacak parselasyon planlarında geçerli olması sebebiyle henüz uygulama örneği ve buna bağlı olarak gerçekleşen olumlu ya da olumsuz etkileri tespit edilememiştir.

$\mathrm{Bu}$ dönem içerisinde fiili ve hukuki el atılan taşınmazlara ilişkin geçerli olan hükümler değişmemiştir. Bu dönemde düzenleme ortaklık payına konu kullanımlardan yol, meydan, ibadet yerleri, park ve çocuk bahçeleri hariç olmak üzere yapı yapılabilecek diğer alanlarda kısıtlılığının ortadan kaldırılmasına yönelik düzenlemeler yapılarak hukuki el atma kavramı 
kapsamındaki taşınmazların sayısı azaltılmıştır.

\section{Sonuçlar ve Öneriler}

Bu makalede, kamulaştırmasız el atma kavramının tüzel gelişiminin tanımlanması ve incelenmesi amaçlanmıştır. Bu amaca ulaşmak üzere kamulaştırmasız el atma kavramı, 1956 ile 2020 yılları arasındaki temel kanun düzenlemeleri ve yargı kararları bakımından bir süreç içerisinde incelenmiş ve farklı hükümlerin geçerli olduğu dönemlere ayrılmıştır. Bu dönemlerin başlangıcını YİBBGK’nin 16.05.1956 tarih ve E: 1956/1, K: 1956/6-7 sayılı İçtihadı Birleştirme Kararı (URL-5) oluşturmaktadır. Kamulaştırmasız el atma kavramı, ilk kez bu kararda kabul edilmiştir. Bu karar sonrasında düzenlenen 09.10.1956 tarihli ve 6830 sayılı İstimlâk Kanunu'nda herhangi bir hükme yer verilmemiş ancak bu tarihe kadar kamulaştırması yapılmayan taşınmazlar, 12.01.1961 tarihli ve 221 sayılı Amme Hükmi Şahıslar veya Müesseseleri Tarafından Fiilen Amme Hizmetlerine Tahsis Edilmiş Gayrimenkuller Hakkındaki Kanun ile kamulaştırılmış sayılmıştır. Bu dönemden sonra, 08.11.1983 tarihli ve 2942 sayılı Kamulaştırma Kanunu’nun 38'inci maddesiyle kamulaştırmasız el atılan taşınmazlara, el atma tarihinden başlamak üzere yirmi yıl ile sınırlayan hak düşürücü süre getirilmiştir. Ancak bu düzenleme, Anayasa Mahkemesi'nin 10.04.2003 tarihli, E: 2002/112 ve K: 2003/33 sayılı kararıyla (URL-7) iptal edilmiştir. İptal kararı sonucu ortaya çıkan uygulama farklılı̆̆ını ve mağduriyetleri gidermek üzere, 08.06.2010 tarihli ve 5999 sayılı Kanun ile 2942 sayılı Kamulaştırma Kanunu'na istisnai hükümler içeren geçici 6'ncı madde eklenmiştir. Ayrıca kamulaştırmasız el atma kavramının kapsamı, YHGK'nin 15.12.2010 gün ve 2010/5-662 esas, 2010/651 sayılı kararıyla (URL-5) hukuki el atmaları da kapsayacak şekilde genişletilmiştir. Bu tarihten sonra geçici 6'ncı madde ile getirilen istisnai hükümlerin geleceğe yönelik olarak uygulanmasını amaçlayan 25.02.2011 tarihli ve 6111 sayılı Kanun ile düzenlenen hükümler, 01.11.2012 tarihli ve E:2010/83, K:2012/169 sayılı Anayasa Mahkemesi kararıyla (URL-8); 11.06.2013 tarihli ve 6487 sayılı Kanun ile düzenlenen hükümler, 13.11.2014 tarihli ve E: 2013/95, K: 2014/176 sayıl1 Anayasa Mahkemesi kararıyla (URL-9); son olarak da 20.08.2016 tarihli ve 6745 say1lı Kanun ile düzenlenen hükümler, 20.12.2018 tarihli ve E: 2016/181, K: 2018/111 sayılı Anayasa Mahkemesi kararlarıyla (URL-16) iptal edilmiştir. Böylelikle, kanun koyucunun kamulaştırmasız el atma davalarında, istisnai hükümlerin geçerli olduğu 09.10.1956 ile 04.11.1983 dönemini genişleterek, istisnai hükümlere tabi olacak taşınmazların arttırılmasını amaçlayan farklı kanunlarla düzenlenen girişimleri, her defasında Anayasa Mahkemesi kararlarıyla iptal edilerek gerçekleştirilememiştir. Kamulaştırma Kanunu'nda yapılan son düzenlemeler ise kamulaştırma bedellerinin ödenmesine ilişkin olup 30.05.2019 tarihli ve 7176 sayılı Bazı Kanunlar ile 635 Sayılı Kanun Hükmünde Kararnamede Değişiklik Yapılmasına Dair Kanun ve 24.12.2019 tarihli ve 7201 sayılı Kamulaştırma Kanunu ile Bazı Kanunlarda Değişiklik Yapılmasına Dair Kanun ile düzenlenmiştir.

Kamulaştırmasız el atmaya ilişkin son dönem, Arazi ve Arsa Düzenlemeleri Hakkında Yönetmelik ile hukuki el atılan taşınmazlara ilişkin düzenlemeleri içermektedir. Bu düzenlemelerin dayanağını da 04.07.2019 tarihli ve 7181 sayılı Tapu Kanunu ve Bazı Kanunlarda Değişiklik Yapılmasına Dair Kanun’un 7’nci maddesi ile değiştirilen 3194 sayılı İmar Kanunu oluşturmaktadır. Yapılan bu değişiklik, hukuki el atılan taşınmazlara ilişkin kısmen sorunun çözümüne odaklanması bakımından, süreçteki diğer düzenlemelerden ayrılmaktadır. Düzenleme ile düzenleme ortaklık payına konu kullanımlardan yol, meydan, ibadet yerleri, park ve çocuk bahçeleri hariç olmak üzere yapı yapılabilecek diğer alanlarda, alanların kamuya geçişi sağlanıncaya kadar maliklerinin talebi hâlinde, ilgili kamu kuruluşunun uygun görüşü alınarak, plandaki kullanım amacına uygun özel tesis yapılabilmesi hüküm altına alınmıştır. Düzenleme, her ne kadar kamusal tesislerin özel mülkiyete dönüşümü kapsamında planlama açısından tartışmalı olsa da taşınmazlardaki kısıtlılığı ve el atma olgusunu ortadan kaldıracaktır. Bu kapsamda, mevcut ve ileride açılacak birçok hukuki el atma davalarını da doğrudan engelleyecektir. Ancak yapılan değişikliğin yeni üretilen planlarda, standart bir işlem haline gelmesi ya da kapsamının farklılaştırılması engellenmelidir. Bu sebeple işlemin yalnızca hukuki el atma kapsamındaki taşınmazlara uygulanması ya da her bir fonksiyon 
bakımından mahalle, ilçe ya da il ölçeğinde, bu kapsamda izin verilebilecek toplam donatı sayısı ya da alanı ile sınırlandırılması sağlanmalıdır.

Kamulaştırmasız el atma sorununun temel sebebi, imar programlarının ve imar planlarının, idarelerin planda yer alan hizmet alanlarının edinimini sağlayacak finansmana ve diğer kaynaklara sahip olmaması sebebiyle uzun yıllar gerçekleştirilememesidir. Ancak bu durum, kanun koyucu tarafından sorunun çözümüne ilişkin çıkarılan kanunların çoğunda göz ardı edilmiştir. Kamulaştırmasız el atma kavramına ilişkin her bir dönemde geçerli olan hükümler, kanun koyucunun kamulaştırmasız el atma problemine olan yaklaşımı, yüksek yargı makamlarının duruşu, maliklerin mülkiyet haklarına ve idarelere olan etkileri ve elde edilen sonuçlar bakımından irdelenmiştir. Bu kapsamda yapılan değerlendirmeler, her bir dönem içerisinde verilmiştir. Özet olarak 1956 yılından günümüze kadar farklı hükümlerin geçerli olduğu her bir dönemde, kanun koyucunun kamulaştırmasız el atmaya ilişkin temel yaklaşımı; kamulaştırmasız el atılan taşınmazların kapsamının daraltılması, kamulaştırılmış sayılması, mülkiyet haklarının kısıtlanması ya da ötelenmesi, mülkiyet hakkını kısıtlayan hükümlere göre sonuçlandırılan dava sayısının arttırılması gibi mülkiyet hakkının ölçüsüz biçimde sınırlandırılmasına ve hakkın özüne dokunarak kullanılamaz hâle gelmesine yol açacak niteliktedir. Süreç içinde kanun koyucunun mülkiyet hakkını kısıtlayıcı benzer yaklaşımları, sıklıkla yüksek mahkeme kararlarına konu olmuş, bazı hükümler iptal edilirken bazı hükümler günümüze kadar yürürlükte kalmıştır. Bu durum, kamulaştırmasız el atma kavramını düzenleyen hükümlerin, süreç içinde bir karmaşa haline gelmesine ve farklı dönemlerde el atmanın niteliğine ve tarihine göre farklılaşmasına sebep olmuştur.

Kamulaştırmasız el atmaya ilişkin 1950'lerden başlayan ve 2020 yılına gelen süreç, kanun düzenlemeleri ve yargı kararlarıyla şekillenmiş ve geçerli hükümler, el atmanın hukuki ya da fiili olmasına bağlı olarak ayrışmıştır. Tüzede, fiili el atmalara ilişkin hükümler, el atmanın gerçekleştiği tarihe bağlı olarak üç farklı zaman aralığı olarak düzenlenmiştir. 09.10.1956 tarihinden önce gerçekleşen tüm fiili el atmalarda, 12.01.1961 tarihli ve 221 sayılı Amme Hükmi Şahıslar veya Müesseseleri Tarafından Fiilen Amme Hizmetlerine Tahsis Edilmiş Gayrimenkuller Hakkındaki Kanun esasları geçerlidir. 09.10.195604.11.1983 arasında gerçekleşen fiili el atmalarda, 2942 sayılı Kamulaştırma Kanunu'nun geçici 6'ncı maddesinde belirtilen esaslar geçerlidir. 04.11.1983 tarihinden sonra gerçekleşen el atmalarda ise her ne kadar kanun koyucu tarafindan 09.10.1956 - 04.11.1983 tarihlerinde el atılan taşınmazlara ilişkin hükümlerin geçerli olmasına yönelik 6111, 6487 ve 6745 sayılı Kanun'lar düzenlenmiş olsa da her biri Anayasa Mahkemesi tarafından iptal edildiğinden (URL-8; URL-9), kamulaştırmasız el atmanın tüzel süreç içinde ilk defa tanındığı YİBBGK’nin 16.05.1956 tarih ve E: 1956/1, K: 1956/6-7 sayılı İçtihadı Birleştirme Kararında (URL-5) belirtilen esaslar uygulanacaktır. Tüzede, hukuki el atmalara ilişkin hükümler ise el atmanın niteliğine bağlı olarak ikiye ayrılmaktadır. Hukuki el atmanın, uygulama imar planlarında umumi hizmetlere ve resmî kurumlara ayrılmak suretiyle mülkiyet hakkının özüne dokunacak şekilde tasarrufu hukuken kısıtlanan taşınmazlara ilişkin olması durumunda, 6745 sayılı Kanun hükümleri geçerlidir. Ayrıca bu taşınmazlar için belirli koşullar altında, plandaki kullanım amacına uygun özel tesis yapılabilmesi mümkündür. Bu taşınmazlar dışında, konumu itibariyle kısıtlı olan ve uygulama imar planı haricindeki planlarla ya da Kültür ve Tabiat Varlıklarını Koruma Kanunu, Boğaziçi Kanunu gibi kanunların uygulamasıyla tasarrufu kısıtlanan taşınmazlar hakkında, YHGK'nin 15.12.2010 tarihli, E: 2010/5-662, K: 2010/651 sayılı kararında (URL-5) belirtilen esaslar geçerlidir.

\section{Kaynaklar}

Bayındırlık ve İskân Bakanlığı. (2009). Bayındırlık ve İskân Bakanlığı Kentleşme Şurâsı 2009 Komisyon Raporları, Çevre ve Şehircilik Bakanlığ1, https://webdosya.csb.gov.tr/db/kentges/editordosya/komisyon_raporlari.pdf (Erişim Tarihi: 19 Haziran 2020)

Çağdaş, V. (2001). 2942 Sayılı Kamulaştırma Yasası'nda Yapılan Değişikliklere Taşınmaz Değerlemesi Açısından Bakış, Mülkiyet, 42, 
16-19.

Demir, K., \& Çabuk, S. (2010). Türkiye'de metropoliten kentlerin nüfus gelişimi. Erciyes Üniversitesi Sosyal Bilimler Enstitüsü Dergisi, 1(28), 193-215.

Kaplan, G. (2012). Yeni Yasal Düzenlemelere Göre Kamulaştırmasız El Koyma Sebebiyle Doğan Tazmin Hakkının Tabi Olduğu Usul ve Esaslar, Türkiye Barolar Birliği Dergisi, 2012/99, 125-150.

Karaca, E. (2018). Kamulaştırmasız El Koymanın Unsurları ve Kamulaştırmasız El Koymaya Karşı Yargısal Başvuru Yolları, Türkiye Barolar Birliği Dergisi, 2018/137, 273-309.

Yalçınduran, T. (2017). 6745 Sayılı Kanun ile Hukuki El Koymalara Dair Yapılan Değişiklikler ile Hukuki ve Fiili El Koymalara Uygulanacak Hükümler, Ankara Üniversitesi Hukuk Fakültesi Dergisi, 66(2), 491-515.

Yavuz, S. (2018). Imar Hukukunda Hukuki El Atma (Yüksek Lisans Tezi), Hacettepe Üniversitesi, Sosyal Bilimler Enstitüsü, Ankara, Türkiye.

URL-1: Türkiye İstatistik Kurumu, Adrese Dayalı Nüfus Kayıt Sistemi Verileri, http://www.tuik.gov.tr/PreTablo.do?alt_id=1059, (Erişim Tarihi: 19 Haziran 2020).

URL-2: ÇŞB. (2011). 2011 yılı KENTGES Belediyeler Anketi Raporu, Çevre ve Şehircilik Bakanlı̆̆g, https://webdosya .csb.gov.tr/db/kentges/editordosya/anket_381.pdf, (Erişim Tarihi: 19 Haziran 2020).

URL-3: ÇŞB. (2014). 2013-2014 yılı KENTGES Belediyeler Anketi Raporu, Çevre ve Şehircilik Bakanlığ1, https://webdosya .csb.gov.tr/db/kentges/editordosya/kentges_2014_anket_raporu.pdf, (Erişim Tarihi: 19 Haziran 2020).

URL-4: ÇŞB. (2016). 2016 yılı KENTGES Belediyeler Anketi Raporu, Çevre ve Şehircilik Bakanlığı, https://webdosya .csb.gov.tr/db/kentges/icerikler/anket-raporu-2016-v9-20191128081146.pdf, (Erişim Tarihi: 19 Haziran 2020).

URL-5: HukukTürk Hukuk Portalı, http://www.hukukturk.com, (Erişim Tarihi: 19 Haziran 2020).

URL-6: 21 Şubat 2008 tarihli ve 26794 sayılı Resmî Gazete, Anayasa Mahkemesi'nin 17.01.2008 tarihli ve E: 2004/25, K: 2008/42 sayıl1 kararı, https://www.resmigazete.gov.tr/eskiler/2008/02/20080221-14.htm, (Erişim Tarihi: 19 Haziran 2020).

URL-7: 4 Kasım 2003 tarihli ve 25279 sayılı Resmî Gazete, Anayasa Mahkemesi’nin 10.04.2003 tarihli, E: 2002/112 ve K: 2003/33 sayıl1 kararı, https://www.resmigazete.gov.tr/eskiler/2003/11/20031104.htm\#11, (Erişim Tarihi: 19 Haziran 2020).

URL-8: 22 Şubat 2013 tarihli ve 28567 sayılı Resmî Gazete, Anayasa Mahkemesi’nin 01.11.2012 tarihli ve E: 2010/83, K: 2012/169 sayılı kararı, https://www.resmigazete.gov.tr/eskiler/2013/02/20130222-10.htm, (Erişim Tarihi: 19 Haziran 2020).

URL-9: 13 Mart 2015 tarihli ve 29294 sayılı Resmî Gazete, Anayasa Mahkemesi’nin 13.11.2014 tarihli ve E: 2013/95, K: 2014/176 sayıl1 kararı, https://www.resmigazete.gov.tr/eskiler/2015/03/20150313-10.pdf, (Erişim Tarihi: 19 Haziran 2020).

URL-10: 29 Haziran 2000 tarihli ve 24093 sayılı Resmî Gazete, Anayasa Mahkemesi'nin 29.12.1999 tarihli ve E: 1999/33, K: 1999/51 sayılı kararı, https://www.resmigazete.gov.tr/eskiler/2000/06/20000629.htm\#11, (Erişim Tarihi: 19 Haziran 2020).

URL-11: Anayasa Mahkemesi Hüseyin Ünal başvurusu, T: 20.09.2018 ve Başvuru No: 2017/24715; https://kararlarbilgibankasi.anayasa.gov.tr/BB/2017/24715, (Erişim Tarihi: 19 Haziran 2020)

URL-12: Anayasa Mahkemesi Bülent Eren ve Diğerleri Başvurusu, T: 31.10.2018, Başvuru No: 2017/27308 https://kararlarbilgibankasi.anayasa.gov.tr/BB/2017/27308, (Erişim Tarihi: 19 Haziran 2020)

URL-13: Ankara 2’nci İdare Mahkemesinin E:2016/196 sayılı kararı, https://www.anayasa.gov.tr/Kararlar/GenelKurul/Basvuru_Karari 12018-34.pdf, (Erişim Tarihi: 19 Haziran 2020).

URL-14: Adana 3. İdare Mahkemesinin E:2017/41 say11 karar1, https://www.anayasa.gov.tr/Kararlar/GenelKurul/Basvuru_Karari/201734.pdf, (Erişim Tarihi: 19 Haziran 2020).

URL-15: 25 Mayıs 2018 tarihli ve 30431 sayılı Resmî Gazete, Anayasa Mahkemesi'nin 28.03.2018 tarihli ve E: 2016/196 ve K: 2018/34 sayılı kararı, https://www.resmigazete.gov.tr/eskiler/2018/05/20180525-14.pdf, (Erişim Tarihi: 19 Haziran 2020).

URL-16: 05 Nisan 2019 tarihli ve 30736 sayılı Resmî Gazete, Anayasa Mahkemesi'nin 20.12.2018 tarihli ve E: 2016/181, K: 2018/111 sayılı kararı, https://www.resmigazete.gov.tr/eskiler/2019/04/20190405-4.pdf, (Erişim Tarihi: 19 Haziran 2020).

URL-17: Adli İstatistikler 2015, T.C. Adalet Bakanlığı Adli Sicil ve İstatistik Genel Müdürlüğü, https://adlisicil.adalet .gov.tr/Resimler/SayfaDokuman/27820191140372015.pdf, (Erişim Tarihi: 18 Temmuz 2020).

URL-18: Adli İstatistikler 2016, T.C. Adalet Bakanlığ1 Adli Sicil ve İstatistik Genel Müdürlüğü, https://adlisicil.adalet .gov.tr/Resimler/SayfaDokuman/27820191126572016.pdf, (Erişim Tarihi: 18 Temmuz 2020).

URL-19: Adli İstatistikler 2017, T.C. Adalet Bakanlığı Adli Sicil ve İstatistik Genel Müdürlüğü, https://adlisicil.adalet 
.gov.tr/Resimler/SayfaDokuman/2682019155449istatistik2017.pdf, (Erişim Tarihi: 18 Temmuz 2020).

URL-20: Adli İstatistikler 2018, T.C. Adalet Bakanlığ1 Adli Sicil ve İstatistik Genel Müdürlüğü, https://adlisicil.adalet .gov.tr/Resimler/SayfaDokuman/2082019153842istatistik2018.pdf, (Erişim Tarihi: 18 Temmuz 2020).

URL-21: Ankara Büyükşehir Belediye Meclisinin 14.01.2013 tarihli ve 150 no'lu kararı, https://www.resmigazete.gov.tr/ eskiler/2019/04/20190405-4.pdf, (Erişim Tarihi: 19 Haziran 2020). 